Publisher: GSA

Journal: GEOL: Geology

DOI:10.1130/G38365.1

\title{
Paleo-Asian Oceanic slab under the North China Craton revealed by carbonatites derived from subducted limestones
}

Chunfei Chen ${ }^{1}$, Yongsheng Liu ${ }^{1 *}$, Stephen F. Foley², Mihai N. Ducea ${ }^{3,4}$, Detao He ${ }^{1}$, Zhaochu Hu' ${ }^{1}$, Wei Chen ${ }^{1}$, and Keqing Zong1

${ }^{1}$ State Key Laboratory of Geological Processes and Mineral Resources, School of Earth

Sciences, China University of Geosciences, Wuhan 430074, China

${ }^{2} A R C$ Centre of Excellence for Core to Crust Fluid Systems, Dept. of Earth and Planetary

Sciences, Macquarie University, North Ryde, New South Wales 2109, Australia

${ }^{3}$ Department of Geosciences, University of Arizona, Tucson, Arizona 85721, USA

${ }^{4}$ Faculty of Geology and Geophysics, University of Bucharest, Bucharest, Romania

*E-mail: yshliu@hotmail.com

\begin{abstract}
It is widely accepted that the lithospheric mantle under the North China Craton (NCC) has experienced comprehensive refertilization due to input from surrounding subducted slabs. However, the possible contribution from the Paleo-Asian Oceanic slab from the north is poorly constrained, largely because of the lack of convincing evidence for the existence of this slab under the NCC. We report here carbonatite intruding into Neogene alkali basalts in the Hannuoba region, close to the northern margin of the NCC. Trace element patterns with positive Sr and U anomalies, negative HFSE (Nb, Ta, Zr, Hf and Ti) and Ce anomalies, high ${ }^{87} \mathrm{Sr} /{ }^{86} \mathrm{Sr}$ ratios (0.70522-0.70796) and high $\delta^{18} \mathrm{O}_{\text {sMow }}$
\end{abstract}


Publisher: GSA

Journal: GEOL: Geology

DOI:10.1130/G38365.1

values (22.2-23\%) indicate that this carbonatite had a limestone precursor. However, the presence of coarse-grained mantle-derived clinopyroxene, orthopyroxene and olivine, and chemical features of the carbonates suggest that the carbonate melts were derived from the mantle. The carbonates have high ${ }^{143} \mathrm{Nd} /{ }^{144} \mathrm{Nd}$ ratios $(0.51282-0.51298)$ and show negative correlation between $\mathrm{CaO}$ and $\mathrm{Ni}$ contents, resulting from reaction between carbonate melt and peridotite. Considering the regional tectonic setting, the carbonatite probably formed by melting of subducted sedimentary carbonate rocks that formed part of the Paleo-Asian Oceanic slab, thus could provide the first direct evidence for the presence of the Paleo-Asian Oceanic slab beneath the NCC.

\section{INTRODUCTION}

Carbonate platforms occur quite commonly in oceanic realms. Small tropical oceans, exemplified by many segments of the Tethyan ocean in Europe, were covered with extensive carbonate platforms, found today in classic Alpine fold and thrust belts. Clearly, some of these materials are subducted to mantle depths where they undergo decarbonation reactions and may be involved in partial melting (Collins et al., 2015; Doucelance et al.,

2014; Ducea et al., 2005; Hammouda, 2003). Enormous budgets of $\mathrm{CO}_{2}$ at magmatic arcs (Lee and Lackey, 2015) independently require that carbonate is a major player in mass exchange at convergent margins. Subduction magmatism is probably one of the most important tectonic mechanisms responsible for regulating the exchange of $\mathrm{CO}_{2}$ between the Earth’s interior and the atmosphere (McKenzie et al., 2016). Unfortunately, very little 
Publisher: GSA

Journal: GEOL: Geology

DOI:10.1130/G38365.1

observational data exist to provide details on the mechanisms of transport of carbonate materials and $\mathrm{CO}_{2}$ from the surface to mantle depths and back to the Earth's surface via fluid (decarbonation reactions) and melt transport (Liu et al., 2015).

It has been suggested that the lithosphere of the North China Craton (NCC) was successively modified by (1) the southward subduction of the Paleo-Asian oceanic slab (PAOS) between the early Paleozoic and the late Permian, (2) the northward subduction of the Paleo-Tethyan oceanic and Yangtze plates in the Triassic and (3) the westward subduction of the Pacific plate since the Cretaceous (Fig. 1A) (Windley et al., 2010). Although all of these subduction events could have contributed to widespreadlithospheric reactivation and thinning under the NCC (e.g., Griffin et al., 1998), the Pacific plate subduction was generally advocated to account for the lithospheric thinning (Zhu et al., 2011). The contribution of the PAOS and Paleo-Tethyan oceanic slab to lithospheric thinning remains enigmatic, largely because of the lack of convincing evidence for the existence of these slabs under the NCC. If abundant carbonate sediments were transported into deep mantle during oceanic slab subduction, they could have contributed fundamentally to the modification of the chemical and physical properties of the lithospheric mantle by carbonate metasomatism. In turn, subsequent mantle-derived melts (especially carbonatite) could contain the fingerprint of subducted carbonate, which can be used to trace the origin of the subducted slab (Tappert et al., 2009) and outline the crust-mantle recycling of carbonate sediments. 
Publisher: GSA

Journal: GEOL: Geology

DOI:10.1130/G38365.1

Here, we document a carbonatite intrusion with geochemical features of recycled limestone. The intrusion marks the subduction of an overlying carbonate platform of the PAOS, to mantle depths beneath the NCC, providing evidence for recycling of carbonate back to the Earth’s surface by buoyant diapirism and high-degree melting.

\section{SAMPLES, PETROLOGY, AND GEOCHEMICAL COMPOSITIONS}

Samples were collected from a carbonatite intrusion $(0.5-3 \mathrm{~m}$ thick and $>35 \mathrm{~m}$ wide) which intrudes into Neogene basalts (10-22 Ma; Zhu (1998)) at Hannuoba (Fig. 1).

The basalts are distributed along the northern margin of the NCC, and comprise intercalated tholeiitic, transitional and alkali basalts (Zhi et al., 1990). The source of the basalts probably contains abundant garnet-pyroxenite (Liu et al., 2008) or was metasomatized by carbonate-rich fluid (Dupuy et al., 1992). The alkali basalts carry abundant granulite, pyroxenite and peridotite xenoliths (Chen et al., 2001). The evolved Sr-Nd isotopic compositions of some pyroxenite xenoliths indicate involvement of subducted sediments (e.g., Xu, 2002). The carbonatite intrusion occurs in xenolith-free basalt and has a sharp boundary with the basalt layer. The overlying basalt is domed upwards by the invasion of the carbonatite melt (Fig. 1B).

The carbonatite contains aggregates of calcite phenocrysts and medium- to coarse-grained silicate macrocrysts set in a matrix of fine-gained calcite (Fig. 1C-D) indicating rapid quenching. Monomineralic aggregates of interlocking calcite grains (50-100 $\mu \mathrm{m})$ indicate calcite accumulation before quenching. The silicate macrocrysts 
Publisher: GSA

Journal: GEOL: Geology

DOI:10.1130/G38365.1

consist of coarse-grained clinopyroxene (Cpx, 0-15 vol.\%), orthopyroxene (Opx, 0-12 vol.\%), olivine (Ol, $0-10$ vol.\%) and rare spinel (Sp, 0-1.5 vol.\%). Ol is forsteritic (Fo = 90-91) and has low $\mathrm{CaO}$ contents ( $<0.1$ wt.\%) but high Ni contents (2809-3062 ppm), and Opx and Cpx have Mg\# values of 90.8-91.6 and 91.9-93.3 respectively (Table DR1). Many macrocrysts consist of recrystallized pseudomorphs of calcite replacing the silicate

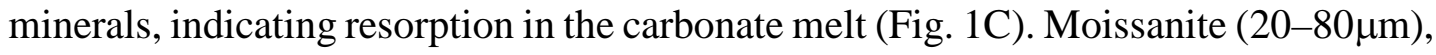
highly disordered graphite $(10-30 \mu \mathrm{m})$ and Na-K chlorides ( $20 \mu \mathrm{m})$ were found (Figure DR1). Moissanite was identified by characteristic Raman peaks at 769, 791 and $970 \mathrm{~cm}^{-1}$ and highly disordered graphite was identified by Raman bands at $1358 \mathrm{~cm}^{-1}$ and $1589 \mathrm{~cm}^{-1}$ (Figure DR1).

Whole-rock compositions of the carbonatites have high $\mathrm{CaO}$ (44.1-53.9 wt.\%), intermediate $\mathrm{MgO}\left(0.8-4.8\right.$ wt.\%) and low alkali contents $\left(\mathrm{Na}_{2} \mathrm{O}<0.01\right.$ wt. $\%$ and $\mathrm{K}_{2} \mathrm{O}$ $<0.05$ wt.\%); many are similar to limestones, and some lie along a mixing trend between limestone and peridotite (Figure DR2). MgO contents in the carbonatites are higher than in limestones (0.13-1.65 wt.\%), and show a negative correlation with CaO. Trace element patterns are similar to sedimentary limestones with notably positive $\mathrm{Sr}$ and $\mathrm{U}$ anomalies and negative high field strength elements (HFSE: Zr, Hf, Nb, Ta, Ti) anomalies (Fig. 2). The incompatible trace element contents of most samples are lower than average limestone, especially for Rb, Ba and heavy rare earth elements (REE) (Fig. 2). Their REE patterns show negative $\mathrm{Ce}$ anomalies $(\mathrm{Ce} / \mathrm{Ce} *=0.2-0.8)$ and positive Eu anomalies 
Publisher: GSA

Journal: GEOL: Geology

DOI:10.1130/G38365.1

$\left(\mathrm{Eu} / \mathrm{Eu}^{*}=1.15-2.98\right)($ Table DR2). The carbonate matrix contains 45.2-52.7 wt.\% CaO,

0.4-1.8 wt.\% MgO and 1.5-5.0 wt.\% $\mathrm{SiO}_{2}$ (Table DR3). Both the carbonate matrix and phenocrysts have higher Ni contents (1-133 ppm) than limestone, and show negative correlations between $\mathrm{CaO}$ and $\mathrm{Ni}$ (Fig. 3A).

Carbonates in the carbonatite intrusion have higher ${ }^{87} \mathrm{Sr} /{ }^{86} \mathrm{Sr}(0.70522-0.70796)$ and slightly higher ${ }^{143} \mathrm{Nd} /{ }^{144} \mathrm{Nd}(0.51282-0.51298)$ than typical carbonatites (Fig. 3B).

${ }^{143} \mathrm{Nd} /{ }^{144} \mathrm{Nd}$ ratios show no correlation with Nd contents $(0.4-2.8 \mathrm{ppm})$, whereas ${ }^{87} \mathrm{Sr} /{ }^{86} \mathrm{Sr}$ ratios correlate negatively with Sr contents (27-306 ppm) (Figure DR3). Rare aragonite veinlets which crosscut one sample possess high Sr contents (2507-6600 ppm) and relatively low ${ }^{87} \mathrm{Sr} /{ }^{86} \mathrm{Sr}$ ratios $(0.70411-0.70683)$ (Table DR4): the post-magmatic fluid that deposited this aragonite might have also partially modified the sample (Fig. 3B). The primary carbonatitic melts represented by the low-Sr samples have the highest ${ }^{87} \mathrm{Sr} /{ }^{86} \mathrm{Sr}$ and ${ }^{143} \mathrm{Nd} /{ }^{144} \mathrm{Nd}$ ratios. The carbonatites are characterized by light carbon isotopic compositions ( $\left(^{13} \mathrm{C}_{\mathrm{VPDB}}=-14.4 \%\right.$ o to $-11.2 \%$ ) but heavy oxygen isotopic compositions $\left(\delta^{18} \mathrm{O}_{\text {sMow }}=22.2 \%\right.$ o to $23 \%$ o $)($ Table DR2).

\section{DISCUSSION}

\section{Mantle Derivation of the Carbonatite}

Possible origins of the $\mathrm{Ol}$ and Cpx macrocrysts in the carbonatite intrusion are reaction products between carbonate melt and the basalt wallrock (Jolis et al., 2013) or peridotite xenocrysts from the mantle that potentially provide records of the ascent process 
Publisher: GSA

Journal: GEOL: Geology

DOI:10.1130/G38365.1

of the carbonatite melts. The compositions of $\mathrm{Ol}(\mathrm{CaO}<0.1$ wt.\%) and $\mathrm{Cpx}(\mathrm{Mg \#}=$

91.9-93.3 and $\mathrm{SiO}_{2}>50.1$ wt.\%) macrocrysts clearly correspond to minerals in mantle peridotites and are unlike products of carbonate melt-basalt interaction (Figure DR4). This conclusion is supported by the Ni contents of Opx and Cpx (Table DR1), which are also typical for mantle minerals (Foley et al., 2006). Ol produced by carbonate melt-basalt interaction would have higher $\mathrm{CaO}$ (>1.31 wt.\%), and Cpx would be characterized by low Mg\# (<84) and low $\mathrm{SiO}_{2}$ content (<45 wt.\%) (Jolis et al., 2013). The temperatures estimated from Cpx+Opx macrocryst pairs are $770-932{ }^{\circ} \mathrm{C}$ (see supplementary information), implying a source depth of $\sim 50 \mathrm{~km}$ for the disrupted mantle xenoliths on the documented geotherm for the northern margin of the NCC (Chen et al., 2001). Hydrous carbonatitic liquids are known to occur at temperatures as low as 870-900 ${ }^{\circ} \mathrm{C}$ (Poli, 2015), at the upper end of this temperature range. Furthermore, highly disordered graphite found in the Hannuoba carbonatite intrusion might be the result of the transformation of diamond during rapid upward migration from the deeper mantle, as suggested by diamond-bearing carbonatite xenoliths (Liu et al., 2015). High Ni contents and high ${ }^{143} \mathrm{Nd} /{ }^{144} \mathrm{Nd}$ ratios of carbonate components in the carbonatite intrusion indicate that interaction between the carbonate melt and peridotite occurred (Fig. 3), as also demonstrated by resorption of olivine macrocrysts in the carbonatite melt (Fig. 1C). In combination, these observations indicate that the carbonatite melt originated at mantle depths, or at least resided long enough in the mantle to acquire these compositional characteristics. 
Publisher: GSA

Journal: GEOL: Geology

DOI:10.1130/G38365.1

\section{Subducted Sedimentary Carbonate Precursor for the Carbonatite}

Mantle-derived carbonatites typically exhibit enriched incompatible trace element contents (e.g., LREE, Nb, Sr and Ba) and steep LREE-enriched patterns (Jones et al., 2013). Contrasting with this, the Hannuoba carbonatites have much lower trace element contents, and show trace element patterns similar to limestone (Fig. 2). Furthermore, they

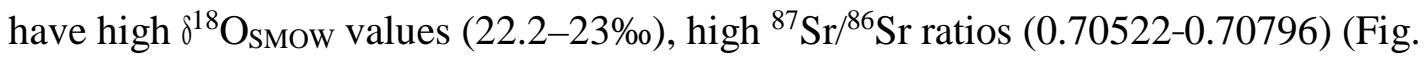
3B), trace element patterns with positive Sr and U anomalies and negative HFSE and Ce anomalies (Fig. 2), all of which are typical features of sedimentary limestones (Jin et al., 2009). In the $\mathrm{CaO}-\mathrm{MgO}-\mathrm{SiO}_{2}$ plot, they form a trend consistent with interaction between pure limestone and peridotite (Figure DR2): their ${ }^{87} \mathrm{Sr} /{ }^{86} \mathrm{Sr}$ and ${ }^{143} \mathrm{Nd} /{ }^{144} \mathrm{Nd}$ ratios and high Ni contents can be modeled by simple mixing between limestone and peridotite (Fig. 3). Taken together, these features suggest the carbonatite intrusion formed from melts of subducted limestone, which interacted with peridotite at depths of at least $50 \mathrm{~km}$ and possibly $150 \mathrm{~km}$, incorporating peridotite minerals as xenocrysts.

The incompatible trace elements, especially those highly mobilized in aqueous fluids (e.g., $\mathrm{Rb}$ and $\mathrm{Ba}$ ), have lower concentrations in the Hannuoba carbonatites than in average limestone (Fig. 2), indicating that the subducted limestone precursor could have been partially modified by aqueous fluids in the subduction zone. Furthermore, the much lower HREE contents and positive Eu anomalies in the carbonatites compared to average limestone (Fig. 2) might be attributed to modification by subduction-related $\mathrm{CO}_{3}{ }^{2-}$-rich 
Publisher: GSA

Journal: GEOL: Geology

DOI:10.1130/G38365.1

aqueous fluids. $\mathrm{HREE}^{3+}$ are complexed more strongly by $\mathrm{CO}_{3}{ }^{2-}$ than $\mathrm{LREE}^{3+}$ and similarly $\mathrm{LREE}^{3+}$ are complexed more strongly by $\mathrm{CO}_{3}{ }^{2-}$ than $\mathrm{Eu}^{2+}$ (Bau, 1991), so that $\mathrm{HREE}^{3+}$ would be removed easily from limestone by a $\mathrm{CO}_{3}{ }^{2-}$-rich fluid, but $\mathrm{Eu}^{2+}$ could be retained.

Melting of limestone is commonly regarded to be restricted to unusually hot regimes (Wyllie and Tuttle, 1960), although the temperatures involved may be reduced in water-bearing conditions (Poli, 2015). Due to the high solidus temperatures but lower density and viscosity, limestone cannot be melted at the top of the subducted slab, but may penetrate into the cold cratonic mantle in the form of solid buoyant diapirs (Behn et al., 2011). The large scale of basalts in the Hannuoba area $\left(\sim 1700 \mathrm{~km}^{2}\right)$ indicates a giant Cenozoic thermal event in the mantle under the northern margin of the NCC, which could have resulted in substantial melting of such limestone diapirs. Limestone is mostly composed of a single calcite phase, so it is reasonable to speculate that high modes of melting of subducted limestone would occur once melting initiates. High-degree melting of a subducted limestone in the mantle was also suggested by Liu et al. (2015) to account for the mantle-derived carbonatite xenoliths from the Dalihu area with the geochemical features of limestone. The Hannuoba carbonatite intrusion may share a similar origin to the carbonatite xenoliths reported by Liu et al. (2015), but were emplaced into the shallow crust. The carbonatite melt might have experienced complex devolatilization during ascent (Russell et al., 2012), which could have produced the low $\delta^{13} \mathrm{C}_{\mathrm{VPDB}}$ values of carbonatite melt (Cartigny et al., 1998) and also yielded extremely local, strongly reducing conditions 
Publisher: GSA

Journal: GEOL: Geology

DOI:10.1130/G38365.1

that permitted the formation of moissanite (Shiryaev and Gaillard, 2014). This would explain both the much lower ${ }^{13} \mathrm{C}_{\text {VPDB }}$ values of the Hannuoba carbonatites relative to average limestone $(-0.44 \pm 2 \%$, $(1 \sigma, n=102))$, and the occurrence of moissanites in the Hannuoba intrusion (Figure DR1).

\section{Implications for the Subduction of the Paleo-Asian Oceanic Slab under the NCC}

The ${ }^{87} \mathrm{Sr} /{ }^{86} \mathrm{Sr}$ ratios of sedimentary carbonate rocks have varied with time (Veizer et al., 1999) (Figure DR5), so that the high Sr isotopic compositions can be used to constrain the age of the limestone. ${ }^{87} \mathrm{Sr} /{ }^{86} \mathrm{Sr}$ ratios of marine carbonates increased from $\leq 0.702$ in the Archaean to 0.7069 in the late Neoproterozoic, and then varied within a small range (0.7069-0.7089) during the Phanerozoic. The highest ${ }^{87} \mathrm{Sr} /{ }^{86} \mathrm{Sr}$ ratio (0.70791) of carbonate in the Hannuoba carbonatite represents materials least contaminated by aragonite veins and mantle materials (Fig. 3B), inferring that the age of the limestone source of the carbonatite is most probably between 360 and $580 \mathrm{Ma}$, and certainly not older than $580 \mathrm{Ma}$ (Figure DR5); this is consistent with its derivation from the Paleo-Asian Ocean, which existed between $1 \mathrm{Ga}$ and $250 \mathrm{Ma}$ (Xiao et al., 2003). Furthermore, the carbonatite intrusion occurs $>1000 \mathrm{~km}$ from the trench position of the east Pacific plate and the Qinling-Dabie-Sulu Orogenic belt, but within $200 \mathrm{~km}$ of the northern margin of the NCC (Fig. 1A). The Pacific slab is eliminated as a possible source because it is stagnating in the mantle transition zone beneath the eastern NCC (Zhao et al., 2009) at a depth to which limestone could not be 
Publisher: GSA

Journal: GEOL: Geology

DOI:10.1130/G38365.1

subducted due to its low density and viscosity. These observations suggest that the limestone precursor was most probably derived from the subducted PAOS.

It is noteworthy that Mesozoic carbonatites from Zhuolu and Huairen 50-100 km south of Hannuoba have high ${ }^{87} \mathrm{Sr} /{ }^{86} \mathrm{Sr}$ ratios (0.7055-0.7075) (Yan et al., 2007) (Figs. 1 and 3B) similar to the Hannuoba carbonatite intrusion, implying that they may also be related to the PAOS. Although the Mesozoic Zhuolu and Huairen carbonatites have similarly lower trace element contents than typical carbonatite, they have much higher trace element contents than the Cenozoic Hannuoba intrusion (Fig. 2). This suggests that the Mesozoic carbonatites could have been derived from partial melting of subducted carbonate-rich eclogite rather than limestone. The Hannuoba, Zhuolu and Huairen carbonatites are distributed in a north-south direction, and show increasing trace element contents with increasing distance from the north margin of the NCC (Figs. 2 and 4). The temporal and spatial variations of the Mesozoic and Cenozoic carbonatites are consistent with the interpretation that carbonated eclogite could be subducted deep into the mantle (Hammouda, 2003) before melting, whereas limestone would detach from the downgoing slab to form buoyant diapirs penetrating into the shallow and cold mantle (Behn et al., 2011; Liu et al., 2015) (Fig. 4). Subsequently, a giant Cenozoic mantle thermal event, as indicated by the large-scale Hannuoba basalts, triggered high-degree melting of the limestones, now in the shallower mantle. These carbonatites reconstruct the path of the 
Publisher: GSA

Journal: GEOL: Geology

DOI:10.1130/G38365.1

consumed PAOS under the NCC, which is critical for understanding how subduction zones modulate the global carbon cycle.

\section{ACKNOWLEDGMENTS}

Reviews by Dr. Jussi S. Heinonen, Hugh Smithies and two anonymous reviewers helped improve the manuscript, and are gratefully acknowledged. This research is co-supported by NSFC (41530211, 41125013 and 90914007), the 973 project of Ministry of Science and Technology of China (2013CB429806), the State Administration of Foreign Expert Affairs of China (B07039), SRFDP (20130145110001), MOST Special

Funds of the SKL-GPMR. This is contribution 852 from the ARC Centre of Excellence for Core to Crust Fluid Systems and 1110 in the GEMOC Key Centre.

\section{REFERENCES CITED}

Bau, M., 1991, Rare-earth element mobility during hydrothermal and metamorphic fluid-rock interaction and the significance of the oxidation state of europium: Chemical Geology, v. 93, p. 219-230, doi:10.1016/0009-2541(91)90115-8.

Behn, M.D., Kelemen, P.B., Hirth, G., Hacker, B.R., and Massonne, H.-J., 2011, Diapirs as the source of the sediment signature in arc lavas: Nature Geoscience, v. 4, p. 641-646, doi:10.1038/ngeo1214.

Cartigny, P., Harris, J.W., and Javoy, M., 1998, Eclogitic Diamond Formation at Jwaneng: No Room for a Recycled Component: Science, v. 280, p. 1421-1424, doi:10.1126/science.280.5368.1421. 
Publisher: GSA

Journal: GEOL: Geology

DOI:10.1130/G38365.1

Chen, S.H., O’Reilly, S.Y., Zhou, X.H., Griffin, W.L., Zhang, G.H., Sun, M., Feng, J.L., and Zhang, M., 2001, Thermal and petrological structure of the lithosphere beneath Hannuoba, Sino-Korean Craton, China: Evidence from xenoliths: Lithos, v. 56, p. 267-301, doi:10.1016/S0024-4937(00)00065-7.

Collins, N.C., Bebout, G.E., Angiboust, S., Agard, P., Scambelluri, M., Crispini, L., and John, T., 2015, Subduction zone metamorphic pathway for deep carbon cycling: II. Evidence from HP/UHP metabasaltic rocks and ophicarbonates: Chemical Geology, v. 412, p. 132-150, doi:10.1016/j.chemgeo.2015.06.012.

Doucelance, R., Bellot, N., Boyet, M., Hammouda, T., and Bosq, C., 2014, What coupled cerium and neodymium isotopes tell us about the deep source of oceanic carbonatites: Earth and Planetary Science Letters, v. 407, p. 175-186, doi:10.1016/j.epsl.2014.09.042.

Ducea, M.N., Saleeby, J., Morrison, J., and Valencia, V.A., 2005, Subducted carbonates, metasomatism of mantle wedges, and possible connections to diamond formation: An example from California: The American Mineralogist, v. 90, p. 864-870, doi:10.2138/am.2005.1670.

Dupuy, C., Liotard, J., and Dostal, J., 1992, Zr/Hf fractionation in intraplate basaltic rocks: carbonate metasomatism in the mantle source: Geochimica et Cosmochimica Acta, v. 56, p. 2417-2423, doi:10.1016/0016-7037(92)90198-R. 
Publisher: GSA

Journal: GEOL: Geology

DOI:10.1130/G38365.1

Foley, S.F., Andronikov, A.V., Jacob, D.E., and Melzer, S., 2006, Evidence from Antarctic mantle peridotite xenoliths for changes in mineralogy, geochemistry and geothermal gradients beneath a developing rift: Geochimica et Cosmochimica Acta, v. 70,

p. 3096-3120, doi:10.1016/j.gca.2006.03.010.

Griffin, W.L., Andi, Z., O’Reilly, S.Y., and Ryan, C.G., 1998, Phanerozoic evolution of the lithosphere beneath the SinoKorean craton, in Flower, M.F.J., et al., eds., Mantle dynamics and plate interactions in East Asia: Geodynamics Series: Washington, D.C., American Geophysical Union, v. 27, p. 107-126.

Hammouda, T., 2003, High-pressure melting of carbonated eclogite and experimental constraints on carbon recycling and storage in the mantle: Earth and Planetary Science Letters, v. 214, p. 357-368, doi:10.1016/S0012-821X(03)00361-3.

Jin, Z.J., Zhu, D.Y., Hu, W.X., Zhang, X.F., Zhang, J.T., and Song, Y.C., 2009, Mesogenetic dissolution of the middle Ordovician limestone in the Tahe oilfield of Tarim basin, NW China: Marine and Petroleum Geology, v. 26, p. 753-763, doi:10.1016/j.marpetgeo.2008.08.005.

Jolis, E.M., Freda, C., Troll, V.R., Deegan, F.M., Blythe, L.S., McLeod, C.L., and Davidson, J.P., 2013, Experimental simulation of magma-carbonate interaction beneath Mt. Vesuvius, Italy: Contributions to Mineralogy and Petrology, v. 166, p. 1335-1353, doi:10.1007/s00410-013-0931-0. 
Publisher: GSA

Journal: GEOL: Geology

DOI:10.1130/G38365.1

Jones, A.P., Genge, M., and Carmody, L., 2013, Carbonate melts and carbonatites:

Reviews in Mineralogy and Geochemistry, v. 75, p. 289-322,

doi:10.2138/rmg.2013.75.10.

Lee, C.-T.A., and Lackey, J.S., 2015, Global Continental Arc Flare-ups and Their Relation to Long-Term Greenhouse Conditions: Elements, v. 11, p. 125-130, doi:10.2113/gselements.11.2.125.

Liu, Y.S., Gao, S., Kelemen, P.B., and Xu, W.L., 2008, Recycled crust controls contrasting source compositions of Mesozoic and Cenozoic basalts in the North China Craton: Geochimica et Cosmochimica Acta, v. 72, p. 2349-2376, doi:10.1016/j.gca.2008.02.018.

Liu, Y.S., He, D.T., Gao, C.G., Foley, S.F., Gao, S., Hu, Z.C., Zong, K.Q., and Chen, H.H., 2015, First direct evidence of sedimentary carbonate recycling in subduction-related xenoliths: Scientific Reports, v. 5, p. 11547, doi:10.1038/srep11547.

McDonough, W.F., and Sun, S.S., 1995, The composition of the Earth: Chemical Geology, v. 120, p. 223-253, doi:10.1016/0009-2541(94)00140-4.

McKenzie, N.R., Horton, B.K., Loomis, S.E., Stockli, D.F., Planavsky, N.J., and Lee, C.-T.A., 2016, Continental arc volcanism as the principal driver of icehouse-greenhouse variability: Science, v. 352, doi:10.1126/science.aad5787.

Poli, S., 2015, Carbon mobilized at shallow deths in subduction zones by carbonatitic liquids: Nature Geoscience, v. 8, p. 633-637, doi:10.1038/NGEO2464 
Publisher: GSA

Journal: GEOL: Geology

DOI:10.1130/G38365.1

Russell, J.K., Porritt, L.A., Lavallee, Y., and Dingwell, D.B., 2012, Kimberlite ascent by assimilation-fuelled buoyancy: Nature, v. 481, p. 352-356, doi:10.1038/nature10740.

Shiryaev, A.A., and Gaillard, F., 2014, Local redox buffering by carbon at low pressures and the formation of moissanite - natural SiC: European Journal of Mineralogy, v. 26, p. 53-59, doi:10.1127/0935-1221/2013/0025-2339.

Tappert, R., Foden, J., Stachel, T., Muehlenbachs, K., Tappert, M., and Wills, K., 2009, Deep mantle diamonds from South Australia: A record of Pacific subduction at the Gondwanan margin: Geology, v. 37, p. 43-46, doi:10.1130/G25055A.1.

Veizer, J., et al., 1999, ${ }^{87} \mathrm{Sr} /{ }^{86} \mathrm{Sr}, \delta^{13} \mathrm{C}$ and $\delta^{18} \mathrm{O}$ evolution of Phanerozoic seawater: Chemical Geology, v. 161, p. 59-88, doi:10.1016/S0009-2541(99)00081-9.

Windley, B.F., Maruyama, S., and Xiao, W.J., 2010, Delamination/thinning of sub-continental lithospheric mantle under Eastern China: The role of water and multiple subduction: American Journal of Science, v. 310, p. 1250-1293, doi:10.2475/10.2010.03.

Wyllie, P.J., and Tuttle, O.F., 1960, The system CaO-CO2-H2O and the origin of carbonatites: Journal of Petrology, v. 1, p. 1-46, doi:10.1093/petrology/1.1.1.

Xiao, W.J., Windley, B.F., Hao, J., and Zhai, M.G., 2003, Accretion leading to collision and the Permian Solonker suture, Inner Mongolia, China: Termination of the central Asian orogenic belt: Tectonics, v. 22, p. 1069, doi:10.1029/2002TC001484. 
Publisher: GSA

Journal: GEOL: Geology

DOI:10.1130/G38365.1

Xu, Y. G., 2002, Evidence for crustal components in the mantle and constraints on crustal recycling mechanisms: pyroxenite xenoliths from Hannuoba, North China: Chemical Geology, v. 182, p. 301-322, doi: 10.1016/S0009-2541(01)00300-X.

Yan, G.H., Mu, B.L., Zeng, Y.S., Cai, J.H., Ren, K.X., and Li, F.T., 2007, Igneous Carbonatites in North China Craton: The Temporal and Spatial Distribution, Sr and Nd Isotopic Charateristics and Their Geological Significance (in Chinese with English abstract): Geological Journal of China Universities, v. 13, p. 463-473.

Zhao, D.P., Tian, Y., Lei, J.S., Liu, L., and Zheng, S.H., 2009, Seismic image and origin of the Changbai intraplate volcano in East Asia: Role of big mantle wedge above the stagnant Pacific slab: Physics of the Earth and Planetary Interiors, v. 173, p. 197-206, doi:10.1016/j.pepi.2008.11.009.

Zhi, X.C., Song, Y., Frey, F.A., Feng, J.L., and Zhai, M.Z., 1990, Geochemistry of Hannuoba basalts, eastern China: Constraints on the origin of continental alkalic and tholeiitic basalt: Chemical Geology, v. 88, p. 1-33, doi:10.1016/0009-2541(90)90101-C.

Zhu, B.Q., 1998, Theory and applications of isotope systematics in geosciences: evolution of continental crust and mantle in China (in Chinese): Beijing, Science Press.

Zhu, R.X., Chen, L., Wu, F.Y., and Liu, J.L., 2011, Timing, scale and mechanism of the destruction of the North China Craton: Science China. Earth Sciences, v. 54, p. 789-797, doi:10.1007/s11430-011-4203-4. 
Publisher: GSA

Journal: GEOL: Geology

DOI:10.1130/G38365.1

\section{FIGURE CAPTIONS}

Figure 1. (A) Tectonic framework of the study area (modified from Windley et al., 2010). CAOB = Central Asian Orogenic Belt, QDSOB = Qinling-Dabie-Sulu Orogenic Belt, (B) Field appearance of the carbonatite intrusion. (C) Residual Ol xenocryst partly resorbed by carbonatite melt. (D) Monomineralic aggregates consist of interlocking calcitegrains. CM = carbonate matrix and SC = sparry calcite.

Figure 2. Primitive mantle (PM) normalized trace element patterns for Hannuoba carbonatite intrusion compared to average carbonatite (ACarb) and average limestone (AL) (data sources in the supplementary information). The Mesozoic Zhuolu (ZL) and Huairen (HR) carbonatites are from Yan et al. (2007), and primitive mantle values from McDonough and Sun (1995).

Figure 3. (A) Carbonates in the carbonatite intrusion lie on a trend between pure calcite and peridotite, in contrast to limestones, which vary in $\mathrm{CaO}$ at constantly low Ni. (B) Plot of $\left({ }^{87} \mathrm{Sr} /{ }^{86} \mathrm{Sr}\right)_{\mathrm{I}}-\left({ }^{143} \mathrm{Nd} /{ }^{144} \mathrm{Nd}\right)_{\mathrm{I}}$. Age of the carbonatite intrusion was assumed to be the same as the Hannuoba basalt (22Ma). ${ }^{143} \mathrm{Nd} /{ }^{144} \mathrm{Nd}$ ratios of aragonite veinlets (gray bar) are represented by the intrusion. Solid curves are mixing lines between limestone and 
Publisher: GSA

Journal: GEOL: Geology

DOI:10.1130/G38365.1

Hannuoba peridotite (Per), ticks on curves show 10\% increments. HSr-Carb = carbonatite with $\mathrm{Sr}>60 \mathrm{ppm}$, LSr-Carb = carbonatite with $\mathrm{Sr}<60 \mathrm{ppm}$. G-Pyr = Hannuoba garnet pyroxenite, Basalt $=$ Hannuoba alkali basalts. Other symbols as in Figure 2. See supplementary information for detailed explanation, data sources and modeling parameters.

Figure 4. Schematic illustration of recycling of sedimentary limestone caused by subduction of the PAOS. Symbol key as in Figure 2.

${ }^{1}$ GSA Data Repository item 2016xxx, xxxxxxxx, is available online at http://www.geosociety.org/pubs/ft2016.htm or on request from editing@geosociety.org. 
Figure 1
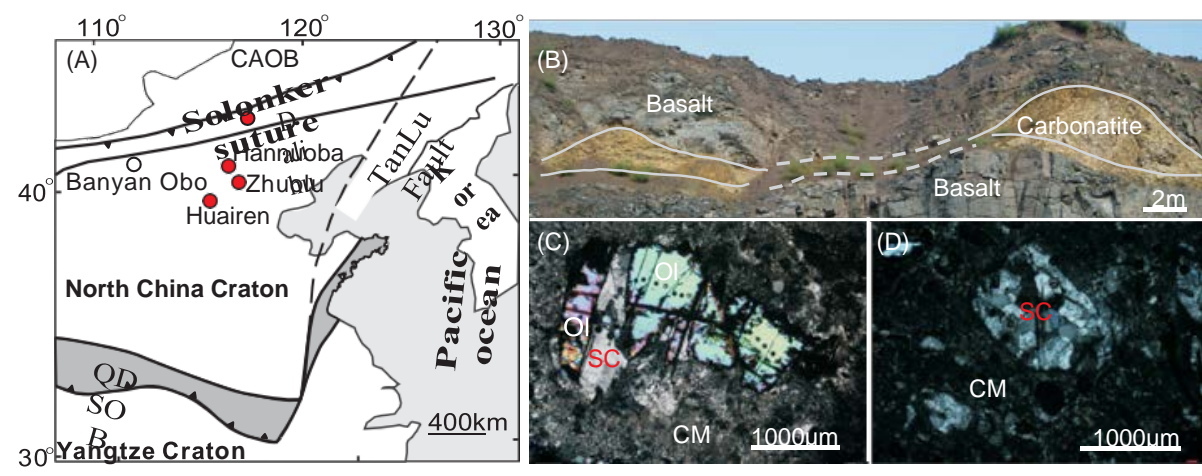
Figure 2

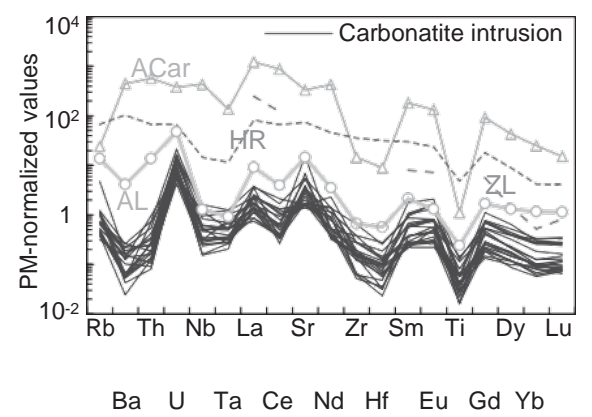




\section{Figure 3}
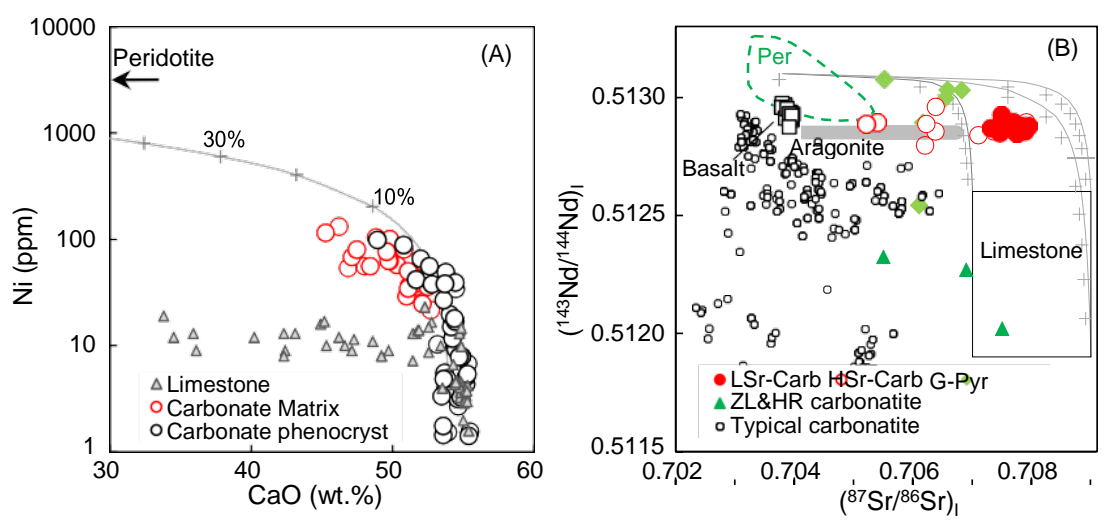
Figure 4

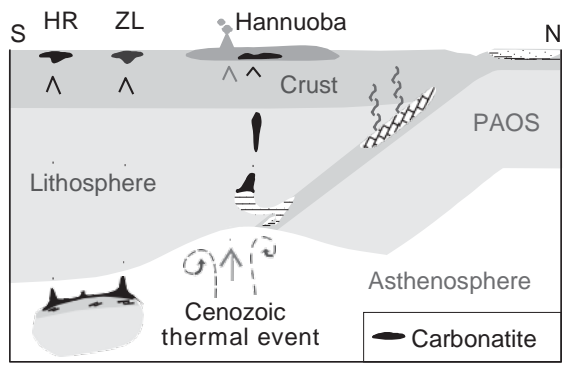




\section{Paleo-Asian Oceanic slab under the North China Craton revealed by carbonatites derived from subducted limestones}

Chunfei Chen ${ }^{1}$, Yongsheng Liu ${ }^{1 *}$, Stephen F. Foley ${ }^{2}$, Mihai N. Ducea ${ }^{3,4}$, Detao He ${ }^{1}$, Zhaochu $\mathrm{Hu}^{1}$, Wei Chen ${ }^{1}$, Keqing Zong ${ }^{1}$

${ }^{1}$ State Key Laboratory of Geological Processes and Mineral Resources, School of Earth Sciences, China University of Geosciences, Wuhan 430074, China

${ }^{2}$ ARC Centre of Excellence for Core to Crust Fluid Systems, Dept. of Earth and Planetary Sciences, Macquarie University, North Ryde, New South Wales 2109, Australia.

${ }^{3}$ Department of Geosciences, University of Arizona, Tucson, AZ 85721, USA

${ }^{4}$ Faculty of Geology and Geophysics, University of Bucharest, Bucharest, Romania

\section{Analytical methods}

Whole rock samples were crushed in a corundum jaw crusher, and the resulting chips were handpicked to exclude the olivine, pyroxene and spinel xenocrysts. About $100 \mathrm{~g}$ of the sample was then powdered in an agate ring mill to less than 200 mesh.

The sample powders were digested by $\mathrm{HF}+\mathrm{HNO}_{3}$ in Teflon bombs and analyzed using an Agilent 7500a ICP-MS at the State Key Laboratory of Geological Processes and Mineral Resources, China University of Geosciences, Wuhan (SKL GPMR-CUG). The detailed sample digestion procedure for ICP-MS analysis is given in Liu et al. (2008a). Analyses of rock standards (BCR-2, BHVO-2 and AGV-2) indicate accuracies are better than $5 \%$ for major elements and $10 \%$ for trace elements.

The selected samples were leached using $1 \mathrm{~N}$ acetic acid to dissolve carbonate for $\mathrm{Sr}$ and $\mathrm{Nd}$ isotopic analyses. The leachate is believed to be the bulk carbonate component in the carbonatite. The chemical separation for $\mathrm{Sr}$ and $\mathrm{Nd}$ isotopic analyses is the same as the description by Gao et al. (2004). Sr-Nd isotopic ratios were determined using a Triton Ti TIMS at the SKL GPMR-CUG. The measured ${ }^{143} \mathrm{Nd} /{ }^{144} \mathrm{Nd}$ and ${ }^{87} \mathrm{Sr} /{ }^{86} \mathrm{Sr}$ ratios were normalized to ${ }^{146} \mathrm{Nd} /{ }^{144} \mathrm{Nd}=0.7219$ and ${ }^{88} \mathrm{Sr} /{ }^{86} \mathrm{Sr}=$ 8.375209, respectively. BCR-2 and GBW04411 were used as the monitor standard materials in this work. Our analytical results $\left({ }^{143} \mathrm{Nd} /{ }^{144} \mathrm{Nd}=0.512629 \pm 0.000006(2 \sigma)\right.$ for BCR-2 and ${ }^{87} \mathrm{Sr} /{ }^{86} \mathrm{Sr}=$ $0.760033 \pm 0.000016(2 \sigma)$ for GBW04411) fit the recommend values $\left({ }^{143} \mathrm{Nd} /{ }^{144} \mathrm{Nd}\right.$ $=0.512636 \pm 0.000002$ (2SD) for BCR-2; ${ }^{87} \mathrm{Sr} /{ }^{86} \mathrm{Sr}=0.76 \pm 0.000006$ (2SD) for GBW04411) within analytical uncertainty.

Major and trace elements of silicate minerals, carbonate matrix and phenocrysts were 
analyzed by LA-ICP-MS with a spot size of $44 \mu \mathrm{m}$ at the SKL GPMR-CUG. Element contents were calibrated against multiple reference materials without applying internal standardization. Details of operating conditions for LA-ICP-MS and data reduction strategy are same as Liu et al. (2008b) for silicate minerals and Chen et al. (2011) for carbonate. Off-line selection and integration of the background and the analyzed signals, along with time-drift correction and quantitative calibration, were performed by ICPMSDataCal (Liu et al., 2008b).

The polished sections were prepared for identifying moissanite and highly disordered graphite using a Thermo Scientific DRX dispersive Raman micro-spectrometer. In order to avoid possible contamination, $\mathrm{Al}_{2} \mathrm{O}_{3}$ abrasive papers only were used to prepare the polished sections. The detailed sample preparation procedure is given in Liu et al. (2015). 


\section{Data sources for carbonatite and limestone}

Carbonatites are compiled from a worldwide database (Bühn, 2008; Bell et al., 1982; Bell and Simonetti, 2010; Halama et al., 2008; Hoernle et al., 2002; Hou et al., 2015; Huang et al., 1995; Mitchell, 2005; Mourao et al., 2010).

Major elements in limestone were collected from worldwide (Armstrong-Altrin et al., 2003; Bellanca et al., 1997; Jin et al., 2009; Klein and Beukes, 1989; Tanaka et al., 2003; Tsikos et al., 2001). Trace elements in limestone collected from worldwide (Bellanca et al., 1997; Jin et al., 2009; Tanaka et al., 2003; Tsikos et al., 2001) are shown for comparison. 


\section{Detailed explanation, data sources and modelling parameters for Fig. 3}

The $\mathrm{CaO}$ versus Ni plot in Fig.3 (A) shows that the carbonates in the carbonatite intrusion trend to high Ni contents, in contrast to limestones. The solid curve is a simple mixing line between limestone and the Hannuoba peridotite (Rudnick et al., 2004): ticks on curves show 10\% increments. Average of peridotites from Hannuoba (Rudnick et al., 2004) is shown for comparison.

(B) Sr-Nd isotopic compositions of the Hannuoba intrusion (this paper). Aragonite veinlets (this paper), limestone (Keto and Jacobsen, 1988; Veizer et al., 1999), typical carbonatites (Bühn, 2008; Bell et al., 1982; Bell and Simonetti, 2010; Halama et al., 2008; Hoernle et al., 2002; Hou et al., 2015; Huang et al., 1995; Mitchell, 2005; Mourao et al., 2010), the Mesozoic carbonatites from Zhuolu (ZL) and Huairen (HR) (Yan et al., 2007), peridotite and garnet pyroxenite xenoliths (Rudnick et al., 2004; Xu, 2002), and alkali basalt (Song et al., 1990) from Hannuoba are shown for comparison. Average $\mathrm{Sr}$ and $\mathrm{Nd}$ contents $(\mathrm{Sr}=380 \mathrm{ppm} ; \mathrm{Nd}=0.66 \mathrm{ppm})$ in Silurian, Devonian and Carboniferous limestones from the Inner Mongolia derived from the Paleo-Asian Ocean (Liu, et al. unpublished data) were used in model calculations. Detailed parameters are listed in the table below.

The trend to high Ni contents shown by the carbonates could reflect mixing in of a lower proportion of peridotite ( 10\%) (Fig. 3A) than that of the trend to high ${ }^{143} \mathrm{Nd} /{ }^{144} \mathrm{Nd}(\sim 30 \%)$ (Fig. 3B). This could be attributed to the transfer of Ni from carbonatite melt to newly growth silicate minerals (i.e. clinopyroxene) during carbonatite-peridotite interaction.

\begin{tabular}{lcc}
\hline Compositional parameters & $\mathrm{Sr}$ & $\mathrm{Nd}$ \\
Limestone (ppm) & 380 & 0.66 \\
Limestone isotope ratios & $0.707-0.709$ & $0.5119-0.5123$ \\
Average of Hannuoba peridotites (ppm) & 14.6 & 1.09 \\
Average of Hannuoba peridotites isotopic ratios & 0.7038 & 0.51310 \\
\hline
\end{tabular}




\section{Figure DR1}
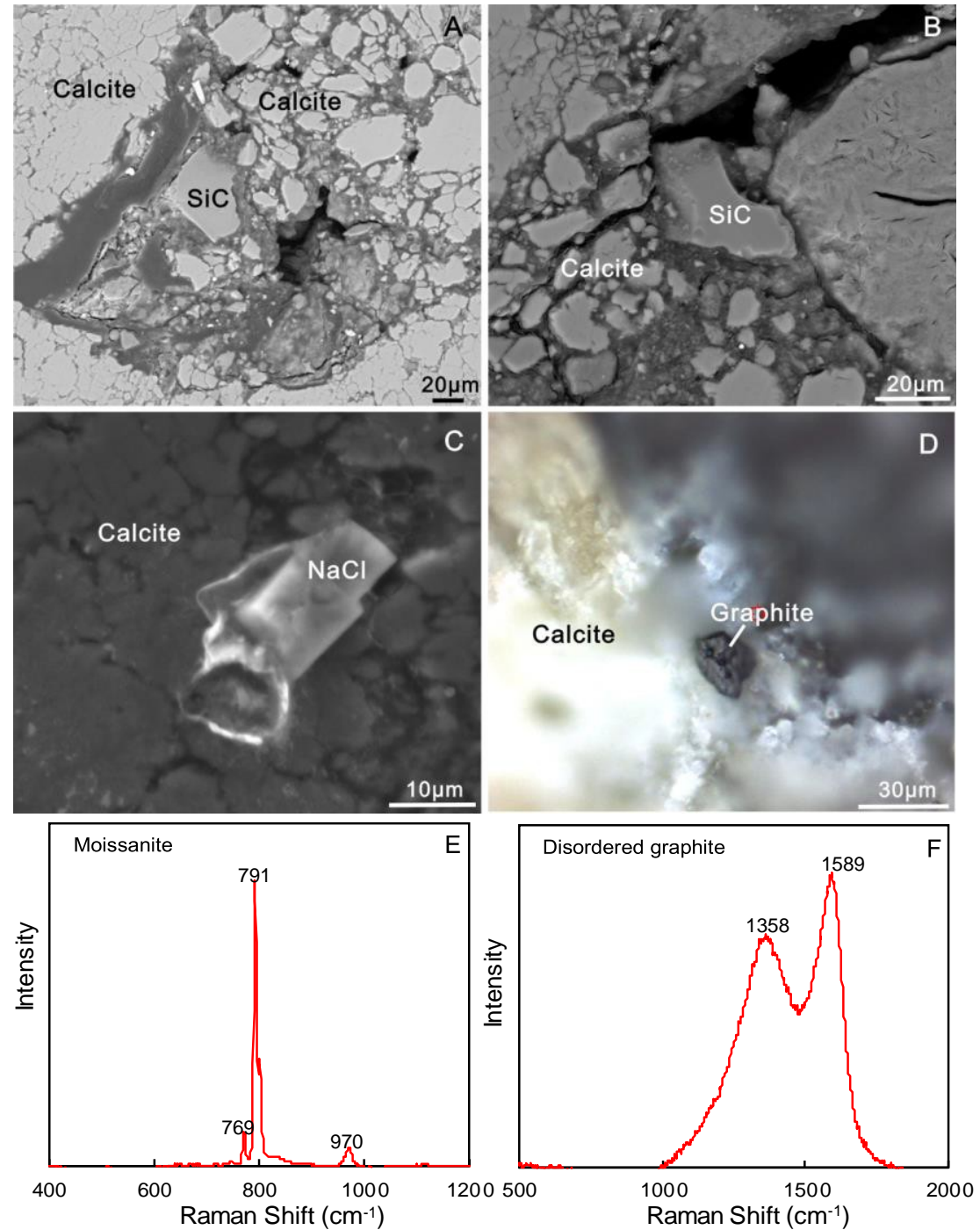

Moissanite (A and B), Na chloride (C) and graphite (D) coexisting with carbonate in the carbonatite intrusion. Raman shift of moissanite (E) and highly disordered graphite (F) in the carbonatite intrusion. 


\section{Figure DR2}

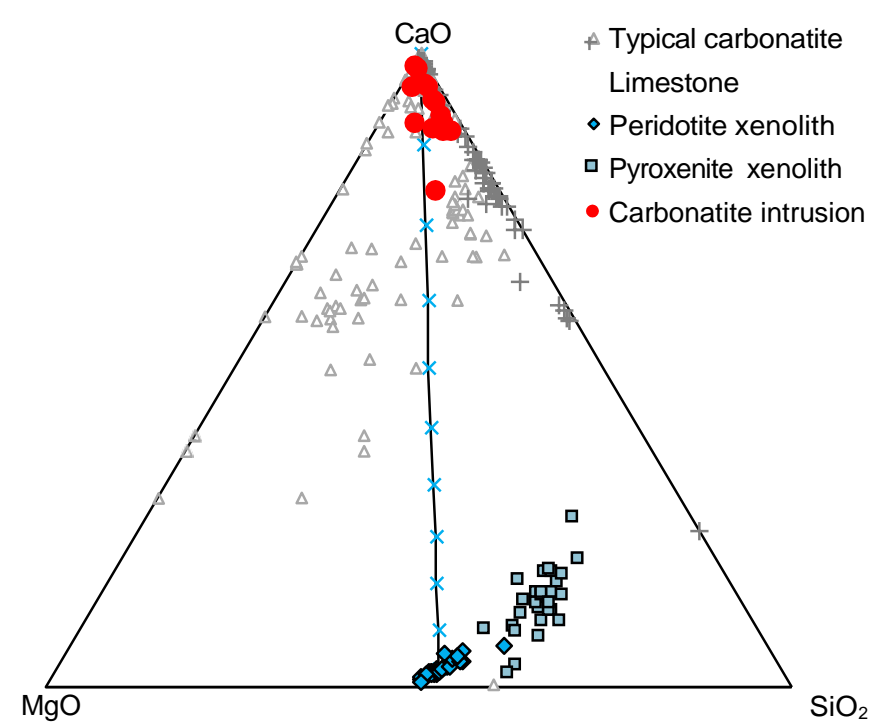

CaO-MgO-SiO ${ }_{2}$ diagram of the Hannuoba carbonatite intrusion (red circles). The solid line with crosses is a mixing line showing $10 \%$ increments between pure limestone and peridotite. Peridotite xenoliths (Rudnick et al., 2004) and pyroxenite veins (Liu et al., 2005; Xu, 2002) in peridotite xenoliths from Hannuoba, limestone (Armstrong-Altrin et al., 2003; Bellanca et al., 1997; Jin et al., 2009; Klein and Beukes, 1989; Tanaka et al., 2003; Tsikos et al., 2001) and typical carbonatites (Bühn, 2008; Bell et al., 1982; Bell and Simonetti, 2010; Halama et al., 2008; Hoernle et al., 2002; Hou et al., 2015; Huang et al., 1995; Mitchell, 2005; Mourao et al., 2010) are shown for comparison. 


\section{Figure DR3}

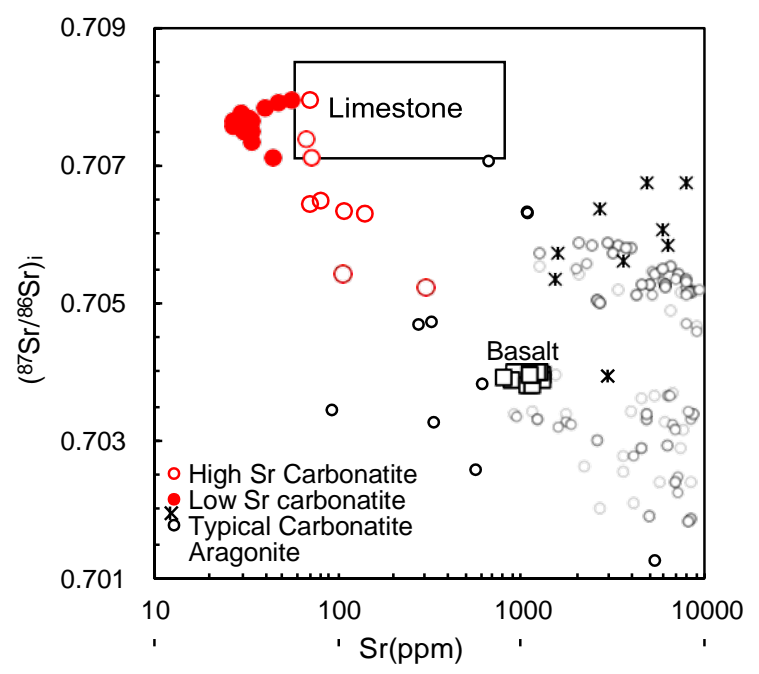

Variations of $\left({ }^{87} \mathrm{Sr} /{ }^{86} \mathrm{Sr}\right)_{\mathrm{I}}$ with $\mathrm{Sr}$ contents for carbonates and aragonite veins in the Hannuoba carbonatite intrusion. The carbonatite intrusion can be classified into two types: low Sr carbonatite (Sr 30 50 ppm) and high Sr carbonatite ( $\mathrm{Sr}>60 \mathrm{ppm}$ ). The isotopic compositions are calculated back to 22 Ma (age of the Hannuoba basalt). The typical carbonatites (data sources as in Figure DR2) and alkali basalts from Hannuoba are shown for comparison. Sr isotopic data for limestone are from Veizer et al. (1999). 


\section{Figure DR4}
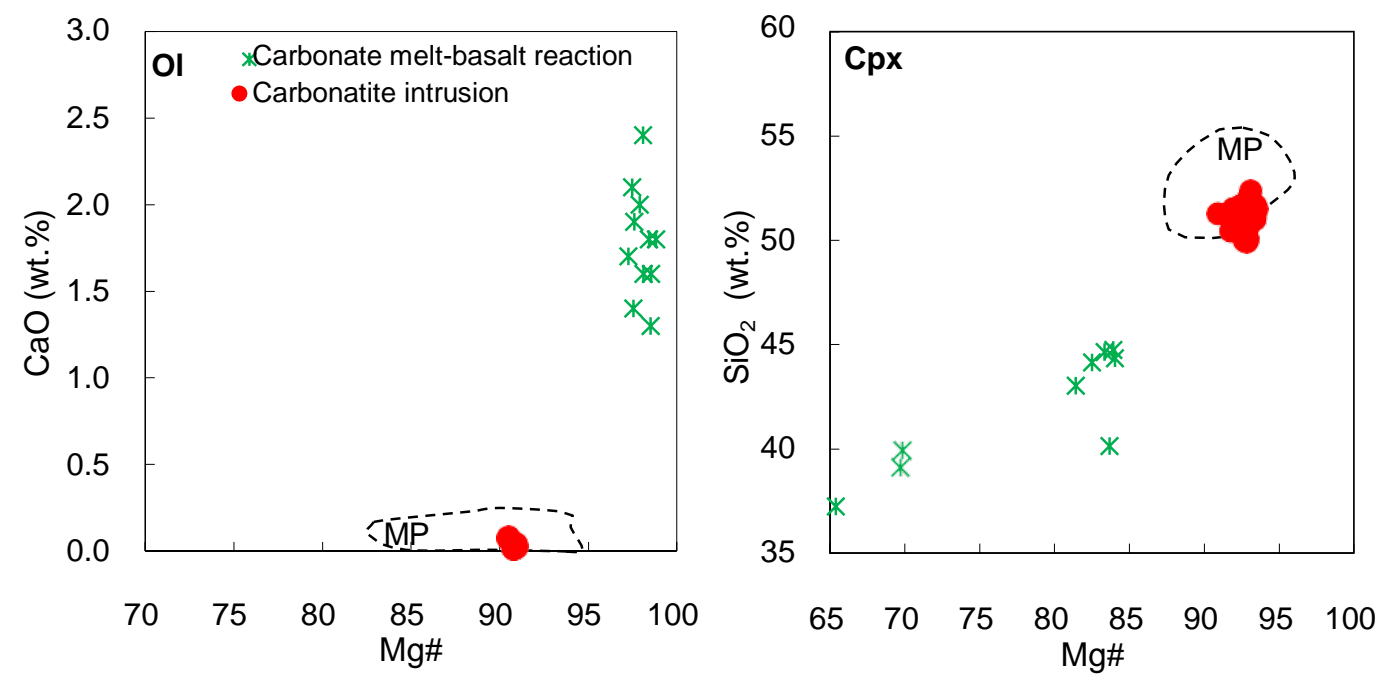

Plots of $\mathrm{Mg \#}$ versus $\mathrm{CaO}$ and $\mathrm{SiO}_{2}$ for $\mathrm{Ol}$ and $\mathrm{Cpx}$ xenocrysts from the Hannuoba carbonatite intrusion, eliminating the possibility that the carbonatite composition could be due to interaction between carbonate and basaltic melt. Data for $\mathrm{Ol}$ and $\mathrm{Cpx}$ formed by carbonate melt-basalt interaction are from Jolis et al. (2013). MP = Range of mantle peridotites from the North China Craton (e.g., Rudnick et al., 2004; Xu et al., 2013). 


\section{Figure DR5}

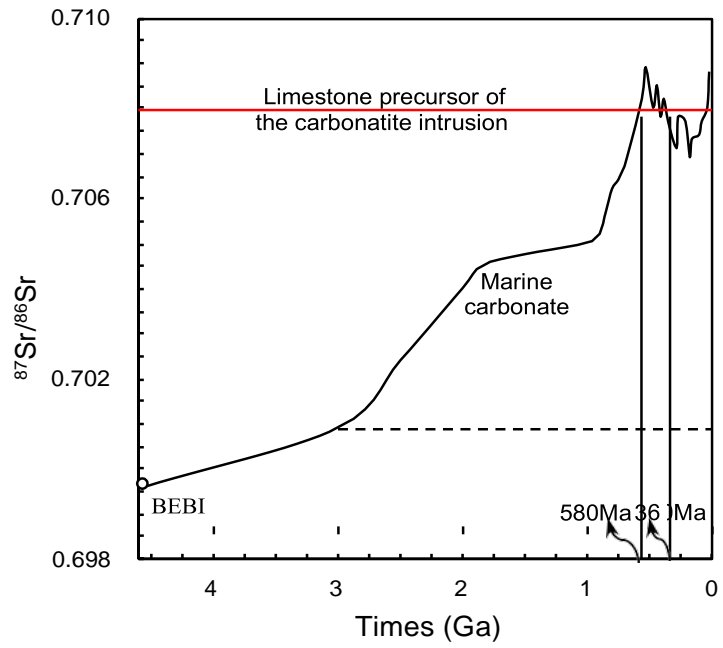

$\left({ }^{87} \mathrm{Sr} /{ }^{86} \mathrm{Sr}\right)_{\mathrm{I}}$ comparison between the limestone precursor of the Hannuoba carbonatite and the evolution line of marine carbonates (Veizer, 1985; Veizer et al., 1999). The intersection points infer that the limestone precursor of the carbonatite intrusion was certainly not older than $580 \mathrm{Ma}$, and most probably between 360 and 580 Ma. BEBI = Bulk-Earth best initial. 


\section{References not cited in main paper}

The temperatures of silicate macrocrysts were estimated using thermometer of Cpx + Opx pairs (Wells, 1977).

(Burke et al., 2003) 


\section{Table DR 1}

Compositions of silicate mineral xenocrysts in the Hannuoba carbonatite intrusion Units are wt.\% for major elements and ppm for $\mathrm{Ni}$.

\begin{tabular}{ccc|ccc|cc|ccc|cc|cc}
\hline Num. & \multicolumn{2}{c|}{ JSB011 } & \multicolumn{3}{c|}{ JSB029 } & \multicolumn{2}{c|}{ JSB012 } & \multicolumn{3}{c|}{ JSB024 } & \multicolumn{2}{c|}{ JSB044 } & \multicolumn{2}{c}{ JSB054 } \\
\hline & Cpx & Opx & Cpx & Ol & Opx & Cpx & Opx & Cpx & Opx & Ol & Cpx & Opx & Cpx & Opx \\
\hline $\mathrm{SiO}_{2}$ & 51.2 & 54.8 & 50.8 & 39.0 & 54.5 & 50.1 & 55.4 & 51.3 & 55.4 & 39.5 & 50.6 & 54.3 & 51.1 & 55.7 \\
$\mathrm{TiO}_{2}$ & 0.30 & 0.08 & 0.11 & 0.00 & 0.04 & 0.33 & 0.07 & 0.29 & 0.08 & 0.00 & 0.32 & 0.08 & 0.34 & 0.08 \\
$\mathrm{Al}_{2} \mathrm{O}_{3}$ & 5.18 & 3.79 & 4.40 & 0.03 & 4.04 & 5.88 & 3.46 & 5.00 & 3.35 & 0.01 & 5.75 & 4.15 & 4.69 & 3.47 \\
$\mathrm{TFeO}$ & 2.36 & 5.27 & 2.68 & 9.15 & 5.97 & 2.21 & 6.11 & 2.07 & 5.70 & 9.12 & 2.25 & 5.59 & 2.70 & 5.76 \\
$\mathrm{MnO}$ & 0.08 & 0.13 & 0.09 & 0.14 & 0.14 & 0.07 & 0.14 & 0.08 & 0.14 & 0.13 & 0.08 & 0.13 & 0.08 & 0.14 \\
$\mathrm{MgO}$ & 16.7 & 34.6 & 17.7 & 51.2 & 33.5 & 15.9 & 33.8 & 16.3 & 34.1 & 50.7 & 16.2 & 34.3 & 17.2 & 33.5 \\
$\mathrm{CaO}$ & 21.6 & 0.65 & 22.5 & 0.08 & 0.98 & 22.9 & 0.46 & 22.3 & 0.51 & 0.03 & 21.9 & 0.61 & 21.3 & 0.62 \\
$\mathrm{Na} 2 \mathrm{O}$ & 1.39 & 0.08 & 0.62 & & 0.05 & 1.44 & 0.05 & 1.34 & 0.06 & & 1.54 & 0.07 & 1.32 & 0.1 \\
$\mathrm{~K} 2 \mathrm{O}$ & 0.00 & 0.00 & 0.01 & 0.00 & 0.00 & 0.00 & 0.00 & 0.00 & 0.00 & 0.00 & 0.00 & 0.00 & 0.01 & 0.00 \\
$\mathrm{P}_{2} \mathrm{O} 5$ & 0.01 & 0.01 & 0.01 & 0.02 & 0.01 & 0.01 & 0.01 & 0.01 & 0.01 & 0.01 & 0.01 & 0.01 & 0.02 & 0.01 \\
$\mathrm{Mg} \#$ & 92.6 & 92.1 & 92.2 & 90.9 & 90.9 & 92.8 & 90.8 & 93.3 & 91.4 & 90.8 & 92.8 & 91.6 & 91.9 & 91.2 \\
$\mathrm{Ni}$ & 348 & 734 & 376 & 2809 & 809 & 287 & 691 & 308 & 713 & 3062 & 327 & 715 & 378 & 755 \\
\hline
\end{tabular}




\section{Table DR 2}

Major and trace element, Sr-Nd isotopic and C-O isotopic compositions of carbonate components in carbonatite intrusion. Units are wt.\% for major elements, ppm for trace elements and \%o for C-O isotopes.

\begin{tabular}{|c|c|c|c|c|c|c|c|c|c|c|c|}
\hline \multicolumn{12}{|c|}{ Carbonatite intrusion (JSB-) } \\
\hline Num. & 12011 & 12022 & 12023 & 12029 & 12032 & 12033 & 12044 & 12046 & 12049 & 12051 & 12053 \\
\hline $\mathrm{SiO}_{2}$ & 5.04 & 3.12 & 3.33 & 5.31 & 2.05 & 4.48 & 4.91 & 4.44 & 0.31 & 1.88 & 6.32 \\
\hline $\mathrm{TiO}_{2}$ & 0.008 & 0.004 & 0.029 & 0.012 & 0.006 & 0.003 & 0.012 & 0.013 & 0.006 & 0.003 & 0.012 \\
\hline $\mathrm{Al}_{2} \mathrm{O}_{3}$ & 0.73 & 0.51 & 0.60 & 0.42 & 0.40 & 0.59 & 1.24 & 1.45 & 0.42 & 0.66 & 1.19 \\
\hline $\mathrm{FeO}$ & 1.41 & 1.03 & 1.57 & 1.63 & 1.32 & 1.55 & 1.11 & 1.30 & 1.17 & 1.04 & 1.28 \\
\hline MgO & 1.39 & 0.90 & 1.04 & 1.58 & 0.88 & 1.08 & 1.35 & 2.18 & 0.80 & 0.85 & 1.59 \\
\hline $\mathrm{CaO}$ & 50.1 & 52.3 & 51.4 & 49.7 & 52.7 & 50.8 & 50.2 & 49.2 & 53.9 & 52.9 & 49.0 \\
\hline $\mathrm{Na}_{2} \mathrm{O}$ & 0.007 & 0.013 & 0.006 & 0.016 & 0.01 & 0.008 & 0.008 & 0.014 & 0.005 & 0.009 & 0.013 \\
\hline $\mathbf{K}_{2} \mathbf{O}$ & 0.019 & 0.014 & 0.02 & 0.023 & 0.014 & 0.017 & 0.014 & 0.016 & 0.012 & 0.026 & 0.016 \\
\hline Sc & 1.02 & 0.40 & 0.97 & 2.25 & 0.89 & 0.80 & 0.69 & 0.65 & 0.36 & 0.29 & 0.80 \\
\hline $\mathbf{V}$ & 2.68 & 1.94 & 2.73 & 2.36 & 1.70 & 3.25 & 2.23 & 3.36 & 1.11 & 1.38 & 2.60 \\
\hline $\mathrm{Cr}$ & 61.5 & 35.4 & 56.4 & 104 & 91.5 & 285 & 16.5 & 57.8 & 8.47 & 2.39 & 125 \\
\hline Co & 4.02 & 1.22 & 3.50 & 6.11 & 2.63 & 3.60 & 1.10 & 7.35 & 3.46 & 1.48 & 10.0 \\
\hline $\mathbf{N i}$ & 113 & 58.3 & 118 & 169 & 98.6 & 113 & 74.4 & 181 & 132 & 96.7 & 145 \\
\hline $\mathbf{R b}$ & 0.69 & 0.25 & 0.67 & 0.41 & 0.24 & 0.58 & 0.29 & 0.38 & 0.27 & 0.65 & 0.41 \\
\hline $\mathrm{Sr}$ & 32.4 & 27.5 & 30.6 & 34.2 & 29.8 & 34.3 & 31.7 & 55.7 & 34.1 & 47.0 & 79.1 \\
\hline $\mathbf{Y}$ & 1.72 & 1.20 & 1.29 & 1.68 & 1.16 & 0.87 & 2.30 & 0.53 & 0.56 & 0.55 & 0.50 \\
\hline $\mathrm{Zr}$ & 2.04 & 0.70 & 4.04 & 1.71 & 0.65 & 0.65 & 2.91 & 2.88 & 1.60 & 1.68 & 1.71 \\
\hline $\mathbf{N b}$ & 0.21 & 0.15 & 0.77 & 0.39 & 0.18 & 0.10 & 0.34 & 0.55 & 0.20 & 0.36 & 0.41 \\
\hline Ba & 0.44 & 0.39 & 0.35 & 0.82 & 0.16 & 0.28 & 0.35 & 1.26 & 0.35 & 1.07 & 1.48 \\
\hline La & 1.44 & 1.66 & 1.48 & 1.56 & 1.53 & 1.10 & 2.36 & 0.56 & 0.57 & 0.88 & 0.48 \\
\hline Ce & 1.34 & 1.73 & 2.24 & 2.16 & 1.91 & 0.83 & 3.54 & 0.67 & 0.58 & 0.69 & 0.63 \\
\hline Pr & 0.37 & 0.27 & 0.31 & 0.39 & 0.27 & 0.15 & 0.62 & 0.11 & 0.11 & 0.12 & 0.095 \\
\hline Nd & 1.73 & 1.16 & 1.43 & 1.79 & 1.12 & 0.69 & 2.85 & 0.49 & 0.46 & 0.48 & 0.43 \\
\hline Sm & 0.43 & 0.22 & 0.35 & 0.42 & 0.23 & 0.14 & 0.73 & 0.099 & 0.10 & 0.10 & 0.089 \\
\hline Eu & 0.25 & 0.12 & 0.13 & 0.20 & 0.12 & 0.089 & 0.32 & 0.049 & 0.056 & 0.042 & 0.034 \\
\hline Gd & 0.41 & 0.23 & 0.28 & 0.40 & 0.26 & 0.15 & 0.60 & 0.11 & 0.10 & 0.098 & 0.079 \\
\hline $\mathbf{T b}$ & 0.07 & 0.03 & 0.04 & 0.06 & 0.03 & 0.02 & 0.08 & 0.01 & 0.01 & 0.01 & 0.01 \\
\hline Dy & 0.36 & 0.14 & 0.22 & 0.30 & 0.14 & 0.11 & 0.43 & 0.081 & 0.080 & 0.059 & 0.078 \\
\hline Ho & 0.07 & 0.03 & 0.04 & 0.05 & 0.03 & 0.02 & 0.08 & 0.01 & 0.02 & 0.01 & 0.02 \\
\hline $\mathbf{E r}$ & 0.17 & 0.063 & 0.094 & 0.12 & 0.071 & 0.050 & 0.19 & 0.036 & 0.040 & 0.029 & 0.034 \\
\hline Tm & 0.028 & 0.008 & 0.011 & 0.019 & 0.009 & 0.006 & 0.024 & 0.005 & 0.005 & 0.004 & 0.004 \\
\hline $\mathbf{Y b}$ & 0.15 & 0.045 & 0.081 & 0.12 & 0.056 & 0.044 & 0.13 & 0.027 & 0.036 & 0.025 & 0.035 \\
\hline Lu & 0.023 & 0.008 & 0.011 & 0.018 & 0.009 & 0.005 & 0.019 & 0.005 & 0.004 & 0.005 & 0.005 \\
\hline Hf & 0.021 & 0.009 & 0.078 & 0.029 & 0.014 & 0.007 & 0.036 & 0.041 & 0.016 & 0.019 & 0.027 \\
\hline Ta & 0.013 & 0.010 & 0.044 & 0.021 & 0.013 & 0.010 & 0.020 & 0.026 & 0.012 & 0.009 & 0.020 \\
\hline $\mathbf{P b}$ & 0.10 & 0.051 & 0.12 & 0.39 & 0.11 & 0.076 & 0.094 & 0.13 & 0.080 & 0.10 & 0.10 \\
\hline Th & 0.02 & 0.01 & 0.06 & 0.03 & 0.01 & 0.01 & 0.02 & 0.02 & 0.01 & 0.03 & 0.02 \\
\hline $\mathbf{U}$ & 0.15 & 0.087 & 0.11 & 0.12 & 0.11 & 0.15 & 0.17 & 0.34 & 0.15 & 0.29 & 0.24 \\
\hline $\mathrm{Ce} / \mathrm{Ce}^{*}$ & 0.45 & 0.63 & 0.80 & 0.68 & 0.72 & 0.50 & 0.71 & 0.66 & 0.56 & 0.51 & 0.71 \\
\hline $\mathbf{E u} / \mathbf{E} \mathbf{u}^{*}$ & 1.78 & 1.62 & 1.17 & 1.50 & 1.42 & 1.80 & 1.44 & 1.40 & 1.62 & 1.27 & 1.21 \\
\hline${ }^{87} \mathbf{R b} /{ }^{86} \mathrm{Sr}$ & 0.0598 & 0.0256 & 0.0621 & 0.0338 & 0.0223 & 0.0476 & 0.0258 & 0.0192 & 0.0222 & 0.0387 & 0.0145 \\
\hline${ }^{87} \mathrm{Sr} /{ }^{86} \mathrm{Sr}$ & 0.707496 & 0.707576 & 0.707780 & 0.707343 & 0.707710 & 0.707640 & $0.707509 \mathrm{c}$ & 0.7079630 & 0.7075090. & .707902 & 0.706383 \\
\hline $2 \sigma$ & 4 & 5 & 5 & 6 & 5 & 7 & 5 & 5 & 17 & 18 & 5 \\
\hline${ }^{147} \mathrm{Sm} /{ }^{144} \mathrm{Nd}$ & 0.1564 & 0.1218 & 0.1539 & 0.1479 & 0.1308 & 0.1321 & 0.1600 & 0.1274 & 0.1427 & 0.1306 & 0.1293 \\
\hline${ }^{143} \mathrm{Nd} /{ }^{144} \mathrm{Nd}$ & 0.512869 & 0.512884 & 0.512866 & 0.512887 & 0.51291 & 0.512885 & 0.512909 & 0.5128940 & 0.5129410 & .512872 & 0.512874 \\
\hline $2 \sigma$ & 5 & 4 & 8 & 4 & 4 & 9 & 4 & 7 & 16 & 12 & 13 \\
\hline$\delta^{13} C_{\text {VPDB }}$ & -12.0 & -12.4 & -12.6 & -13.1 & -11.9 & -12.1 & -11.9 & -11.4 & -12.8 & -11.3 & -12.2 \\
\hline$\delta^{18} \mathrm{O}$ sMow & 22.7 & 22.8 & 22.6 & 22.6 & 22.8 & 22.8 & 22.7 & 22.7 & 22.5 & 22.6 & 22.3 \\
\hline
\end{tabular}


Table DR 2 continued

\begin{tabular}{|c|c|c|c|c|c|c|c|c|c|c|}
\hline \multicolumn{11}{|c|}{ Carbonatite intrusion (JSB-) } \\
\hline Num. & 12055 & 12057 & 12058 & 12061 & 12063 & 12093 & 14005 & 14035 & 14045 & 14009 \\
\hline $\mathrm{SiO}_{2}$ & 7.55 & 2.20 & 0.92 & 5.91 & 2.59 & 3.76 & 7.36 & 3.68 & 16.00 & 2.70 \\
\hline $\mathrm{TiO}_{2}$ & 0.026 & 0.011 & 0.023 & 0.008 & 0.009 & 0.003 & 0.016 & 0.008 & 0.008 & 0.005 \\
\hline $\mathbf{A l}_{2} \mathbf{O}_{3}$ & 1.76 & 0.55 & 1.16 & 0.80 & 0.86 & 0.44 & 1.86 & 0.42 & 0.51 & 1.37 \\
\hline $\mathrm{FeO}$ & 1.27 & 1.13 & 1.64 & 1.13 & 0.91 & 1.17 & 1.28 & 1.45 & 0.52 & 0.73 \\
\hline MgO & 3.00 & 1.18 & 2.03 & 1.10 & 1.43 & 1.24 & 4.81 & 1.56 & 2.03 & 3.35 \\
\hline $\mathrm{CaO}$ & 46.4 & 52.3 & 51.2 & 50.2 & 51.8 & 51.4 & 44.2 & 50.8 & 44.1 & 49.4 \\
\hline $\mathrm{Na}_{2} \mathrm{O}$ & 0.012 & 0.005 & 0.012 & 0.006 & 0.009 & 0.006 & 0.03 & 0.009 & 0.011 & 0.014 \\
\hline $\mathbf{K}_{2} \mathbf{O}$ & 0.015 & 0.013 & 0.02 & 0.013 & 0.024 & 0.014 & 0.012 & 0.012 & 0.039 & 0.013 \\
\hline Sc & 0.70 & 0.37 & 0.95 & 0.42 & 0.40 & 0.52 & 1.57 & 0.80 & 0.36 & 0.40 \\
\hline $\mathbf{V}$ & 3.10 & 1.63 & 3.51 & 1.25 & 1.58 & 1.47 & 7.08 & 3.41 & 1.70 & 1.70 \\
\hline $\mathrm{Cr}$ & 56.2 & 11.0 & 84.2 & 21.6 & 1.48 & 9.75 & 181 & 112 & 13.6 & 21.7 \\
\hline Co & 5.17 & 4.33 & 6.01 & 2.72 & 1.79 & 1.79 & 8.75 & 3.00 & 1.74 & 1.51 \\
\hline $\mathrm{Ni}$ & 127 & 129 & 198 & 119 & 93.3 & 94.1 & 208 & 152 & 156 & 83.9 \\
\hline $\mathbf{R b}$ & 0.41 & 0.30 & 0.45 & 0.27 & 0.74 & 0.43 & 0.19 & 0.32 & 2.84 & 0.22 \\
\hline $\mathrm{Sr}$ & 109 & 106 & 40.1 & 33.8 & 306 & 68.7 & 64.7 & 72.9 & 138 & 63.3 \\
\hline $\mathbf{Y}$ & 1.82 & 0.69 & 0.94 & 0.62 & 0.62 & 3.26 & 1.83 & 0.86 & 0.45 & 0.72 \\
\hline $\mathrm{Zr}$ & 6.76 & 2.02 & 2.92 & 1.77 & 3.98 & 1.45 & 1.26 & 1.30 & 1.67 & 0.54 \\
\hline Nb & 1.06 & 0.34 & 0.63 & 0.31 & 0.78 & 0.10 & 0.22 & 0.17 & 0.31 & 0.21 \\
\hline Ba & 1.45 & 0.44 & 0.86 & 0.39 & 1.71 & 1.71 & 0.92 & 1.01 & 1.07 & 0.67 \\
\hline La & 2.46 & 0.93 & 1.03 & 0.73 & 0.89 & 2.31 & 1.39 & 0.72 & 0.81 & 1.15 \\
\hline Ce & 2.82 & 1.09 & 1.58 & 0.96 & 1.07 & 0.55 & 0.45 & 0.56 & 0.57 & 0.95 \\
\hline Pr & 0.41 & 0.15 & 0.23 & 0.14 & 0.15 & 0.31 & 0.23 & 0.10 & 0.11 & 0.15 \\
\hline Nd & 1.73 & 0.67 & 0.97 & 0.67 & 0.65 & 1.38 & 1.06 & 0.46 & 0.40 & 0.58 \\
\hline Sm & 0.38 & 0.15 & 0.24 & 0.16 & 0.12 & 0.25 & 0.28 & 0.11 & 0.087 & 0.11 \\
\hline Eu & 0.26 & 0.074 & 0.088 & 0.067 & 0.076 & 0.12 & 0.13 & 0.045 & 0.080 & 0.044 \\
\hline Gd & 0.38 & 0.14 & 0.22 & 0.15 & 0.14 & 0.37 & 0.30 & 0.12 & 0.072 & 0.11 \\
\hline $\mathbf{T b}$ & 0.048 & 0.022 & 0.031 & 0.021 & 0.019 & 0.043 & 0.042 & 0.017 & 0.011 & 0.014 \\
\hline Dy & 0.27 & 0.098 & 0.16 & 0.12 & 0.12 & 0.26 & 0.26 & 0.099 & 0.066 & 0.081 \\
\hline Ho & 0.050 & 0.019 & 0.028 & 0.018 & 0.019 & 0.056 & 0.045 & 0.021 & 0.013 & 0.016 \\
\hline Er & 0.13 & 0.047 & 0.076 & 0.050 & 0.040 & 0.16 & 0.13 & 0.051 & 0.040 & 0.040 \\
\hline Tm & 0.019 & 0.007 & 0.010 & 0.005 & 0.007 & 0.023 & 0.017 & 0.007 & 0.007 & 0.0057 \\
\hline $\mathbf{Y b}$ & 0.12 & 0.045 & 0.055 & 0.040 & 0.038 & 0.14 & 0.11 & 0.044 & 0.041 & 0.030 \\
\hline Lu & 0.016 & 0.005 & 0.010 & 0.006 & 0.006 & 0.023 & 0.018 & 0.007 & 0.008 & 0.006 \\
\hline Hf & 0.073 & 0.033 & 0.053 & 0.029 & 0.037 & 0.009 & 0.027 & 0.017 & 0.024 & 0.010 \\
\hline Ta & 0.046 & 0.018 & 0.038 & 0.014 & 0.019 & 0.008 & 0.013 & 0.010 & 0.024 & 0.028 \\
\hline $\mathbf{P b}$ & 0.12 & 0.082 & 0.16 & 0.066 & 0.22 & 0.11 & 0.063 & 0.088 & 0.22 & 0.082 \\
\hline Th & 0.043 & 0.020 & 0.078 & 0.013 & 0.059 & 0.015 & 0.013 & 0.008 & 0.027 & 0.007 \\
\hline $\mathbf{U}$ & 0.29 & 0.11 & 0.13 & 0.16 & 0.44 & 0.19 & 0.19 & 0.20 & 0.32 & 0.18 \\
\hline $\mathrm{Ce} / \mathrm{Ce}^{*}$ & 0.68 & 0.71 & 0.79 & 0.71 & 0.71 & 0.16 & 0.19 & 0.51 & 0.46 & 0.56 \\
\hline $\mathbf{E u} / \mathbf{E} \mathbf{u}^{*}$ & 2.07 & 1.51 & 1.15 & 1.29 & 1.82 & 1.23 & 1.33 & 1.15 & 2.98 & 1.19 \\
\hline${ }^{87} \mathrm{Rb} /{ }^{86} \mathrm{Sr}$ & 0.0105 & 0.0079 & 0.0313 & 0.0224 & 0.0069 & 0.0177 & 0.0082 & 0.0125 & 0.0578 & 0.0098 \\
\hline${ }^{87} \mathrm{Sr} /{ }^{86} \mathrm{Sr}$ & 0.706225 & 0.705401 & 0.707822 & 0.707681 & 0.705222 & 0.707374 & 0.7079080 & .707108 & 0.706217 & 0.706388 \\
\hline $2 \sigma$ & 6 & 5 & 5 & 6 & 5 & 6 & 5 & 5 & 14 & 10 \\
\hline${ }^{147} \mathrm{Sm} /{ }^{144} \mathrm{Nd}$ & 0.1394 & 0.1413 & 0.1554 & 0.1459 & 0.1141 & 0.1145 & 0.1644 & 0.1562 & 0.1351 & 0.1214 \\
\hline${ }^{143} \mathrm{Nd} /{ }^{144} \mathrm{Nd}$ & 0.512906 & 0.512912 & 0.5129 & 0.512903 & 0.512902 & 0.512871 & 0.512918 & 0.512862 & 0.512817 & 0.512976 \\
\hline $2 \sigma$ & 6 & 4 & 5 & 4 & 6 & 5 & 7 & 14 & 6 & 23 \\
\hline$\delta^{13} C_{\text {VPDB }}$ & -12.7 & -14.4 & -13.5 & -13.3 & -13.6 & -11.3 & -11.9 & -11.8 & -11.4 & -11.2 \\
\hline$\delta^{18} O$ sMOW & 22.2 & 22.6 & 22.6 & 22.6 & 22.6 & 23.0 & 22.6 & 22.5 & 22.6 & 23.0 \\
\hline
\end{tabular}

Based on the normalization strategy of bulk components as $100 \%, \mathrm{SiO}_{2}{ }^{*}$ is calculated by $100 \%$ the sum of all other major element concentrations expressed as carbonates. 


\section{Table DR 3}

Compositions of calcite phenocryst (CP) and calcite matrix (CM) in the Hannuoba carbonatite intrusion. Units are wt.\% for major elements and ppm for $\mathrm{Ni}$.

\begin{tabular}{|c|c|c|c|c|c|c|c|}
\hline Sample Name & & $\mathrm{CaO}$ & $\mathrm{MgO}$ & $\mathrm{FeO}$ & $\mathrm{SiO}_{2}$ & $\mathrm{Al}_{2} \mathrm{O}_{3}$ & $\mathrm{Ni}$ \\
\hline JSB011-Cc1-01 & $\mathrm{CP}$ & 55.3 & 0.23 & 0.08 & 0.20 & 0.00 & 6.8 \\
\hline JSB011-Cc1-02 & $\mathrm{CP}$ & 55.5 & 0.20 & 0.05 & 0.18 & 0.00 & 1.6 \\
\hline JSB011-Cc1-03 & $\mathrm{CP}$ & 55.4 & 0.22 & 0.04 & 0.26 & 0.00 & 1.4 \\
\hline JSB012-Cc1-01 & $\mathrm{CP}$ & 53.8 & 0.58 & 0.18 & 0.91 & 0.01 & 49.2 \\
\hline JSB012-Cc1-02 & $\mathrm{CP}$ & 54.5 & 0.48 & 0.10 & 0.61 & 0.00 & 34.4 \\
\hline JSB012-Cc1-03 & $\mathrm{CP}$ & 54.4 & 0.61 & 0.08 & 0.50 & 0.00 & 39.4 \\
\hline JSB012-Cc2-01 & $\mathrm{CP}$ & 54.7 & 0.60 & 0.03 & 0.44 & 0.00 & 2.7 \\
\hline JSB012-Cc2-02 & $\mathrm{CP}$ & 54.6 & 0.68 & 0.03 & 0.40 & 0.00 & 3.2 \\
\hline JSB012-Cc2-03 & $\mathrm{CP}$ & 54.8 & 0.59 & 0.03 & 0.34 & 0.00 & 3.3 \\
\hline JSB024-Cc1-01 & $\mathrm{CP}$ & 53.7 & 1.42 & 0.06 & 0.36 & 0.00 & 3.9 \\
\hline JSB024-Cc1-02 & $\mathrm{CP}$ & 53.5 & 1.62 & 0.06 & 0.41 & 0.00 & 3.4 \\
\hline JSB024-Cc1-03 & $\mathrm{CP}$ & 53.9 & 1.33 & 0.08 & 0.28 & 0.00 & 1.5 \\
\hline JSB024-Cc2-01 & $\mathrm{CP}$ & 54.5 & 0.63 & 0.07 & 0.49 & 0.01 & 9.3 \\
\hline JSB024-Cc2-02 & $\mathrm{CP}$ & 54.5 & 0.45 & 0.13 & 0.58 & 0.02 & 13.2 \\
\hline JSB024-Cc2-03 & $\mathrm{CP}$ & 54.9 & 0.36 & 0.07 & 0.42 & 0.01 & 8.0 \\
\hline JSB029-Cc1-01 & $\mathrm{CP}$ & 53.6 & 1.63 & 0.08 & 0.28 & 0.00 & 1.5 \\
\hline JSB029-Cc1-02 & $\mathrm{CP}$ & 53.6 & 1.59 & 0.09 & 0.31 & 0.00 & 1.8 \\
\hline JSB029-Cc1-03 & $\mathrm{CP}$ & 53.2 & 1.65 & 0.12 & 0.50 & 0.02 & 10.3 \\
\hline JSB029-Cc2-01 & $\mathrm{CP}$ & 54.2 & 0.58 & 0.12 & 0.64 & 0.03 & 11.7 \\
\hline JSB029-Cc2-02 & $\mathrm{CP}$ & 48.9 & 1.04 & 0.98 & 3.30 & 0.21 & 98.9 \\
\hline JSB044-Cc1-04 & $\mathrm{CP}$ & 53.7 & 1.61 & 0.02 & 0.30 & 0.00 & 5.6 \\
\hline JSB044-Cc1-05 & $\mathrm{CP}$ & 53.9 & 1.54 & 0.02 & 0.21 & 0.00 & 4.9 \\
\hline JSB044-Cc1-06 & $\mathrm{CP}$ & 53.6 & 1.74 & 0.02 & 0.23 & 0.00 & 4.9 \\
\hline JSB044-Cc2-03 & $\mathrm{CP}$ & 54.8 & 0.26 & 0.09 & 0.53 & 0.04 & 8.0 \\
\hline JSB044-Cc2-04 & $\mathrm{CP}$ & 54.9 & 0.39 & 0.08 & 0.40 & 0.03 & 7.9 \\
\hline JSB044-Cc2-05 & $\mathrm{CP}$ & 51.6 & 0.46 & 0.50 & 1.99 & 0.40 & 41.8 \\
\hline JSB044-Cc2-06 & $\mathrm{CP}$ & 54.2 & 0.26 & 0.20 & 0.81 & 0.13 & 15.0 \\
\hline JSB054-Cc1-01 & $\mathrm{CP}$ & 54.7 & 0.30 & 0.06 & 0.48 & 0.08 & 7.9 \\
\hline JSB054-Cc1-02 & $\mathrm{CP}$ & 54.9 & 0.47 & 0.03 & 0.33 & 0.01 & 4.4 \\
\hline JSB054-Cc3-05 & $\mathrm{CP}$ & 54.0 & 0.43 & 0.18 & 0.84 & 0.05 & 19.7 \\
\hline JSB054-Cc3-06 & $\mathrm{CP}$ & 54.4 & 0.53 & 0.12 & 0.55 & 0.03 & 17.0 \\
\hline JSB054-Cc3-07 & $\mathrm{CP}$ & 52.8 & 0.44 & 0.42 & 1.39 & 0.17 & 37.9 \\
\hline JSB054-Cc3-08 & $\mathrm{CP}$ & 53.6 & 0.31 & 0.24 & 1.07 & 0.16 & 26.9 \\
\hline JSB054-Cc3-09 & $\mathrm{CP}$ & 55.2 & 0.31 & 0.03 & 0.30 & 0.00 & 4.4 \\
\hline JSB054-Cc3-10 & $\mathrm{CP}$ & 54.4 & 0.39 & 0.16 & 0.70 & 0.04 & 18.0 \\
\hline JSB057-Cc3-02 & $\mathrm{CP}$ & 55.2 & 0.19 & 0.07 & 0.32 & 0.00 & 5.1 \\
\hline JSB057-Cc3-03 & $\mathrm{CP}$ & 55.3 & 0.20 & 0.06 & 0.29 & 0.00 & 5.4 \\
\hline JSB057-Cc1-01 & $\mathrm{CP}$ & 52.0 & 0.53 & 0.53 & 1.79 & 0.16 & 65.8 \\
\hline JSB057-Cc1-02 & $\mathrm{CP}$ & 52.6 & 0.40 & 0.43 & 1.59 & 0.19 & 55.7 \\
\hline JSB057-Cc1-03 & $\mathrm{CP}$ & 53.7 & 0.32 & 0.31 & 1.05 & 0.07 & 38.1 \\
\hline JSB057-Cc1-04 & $\mathrm{CP}$ & 50.8 & 0.45 & 0.72 & 2.54 & 0.34 & 88.6 \\
\hline
\end{tabular}


Table DR 3 continued

\begin{tabular}{cccccccc}
\hline Sample Name & & $\mathrm{CaO}$ & $\mathrm{MgO}$ & $\mathrm{FeO}$ & $\mathrm{SiO}_{2}$ & $\mathrm{Al}_{2} \mathrm{O}_{3}$ & $\mathrm{Ni}$ \\
\hline JSB011-Cc2-01 & $\mathrm{CM}$ & 51.2 & 0.48 & 0.94 & 2.31 & 0.11 & 36.8 \\
JSB011-Cc2-02 & $\mathrm{CM}$ & 51.1 & 0.48 & 0.98 & 2.27 & 0.14 & 36.1 \\
JSB011-Cc2-03 & $\mathrm{CM}$ & 52.7 & 0.41 & 0.58 & 1.54 & 0.08 & 21.7 \\
JSB011-Cc2-04 & $\mathrm{CM}$ & 52.1 & 0.48 & 0.74 & 1.78 & 0.08 & 24.7 \\
JSB024-Cc3-01 & $\mathrm{CM}$ & 51.6 & 0.54 & 0.79 & 2.06 & 0.05 & 36.0 \\
JSB024-Cc3-02 & $\mathrm{CM}$ & 49.8 & 0.69 & 1.15 & 2.97 & 0.08 & 62.9 \\
JSB024-Cc3-03 & $\mathrm{CM}$ & 50.3 & 0.69 & 1.06 & 2.74 & 0.06 & 57.5 \\
JSB024-Cc3-04 & $\mathrm{CM}$ & 48.8 & 0.72 & 1.27 & 3.53 & 0.14 & 104 \\
JSB024-Cc3-05 & $\mathrm{CM}$ & 49.8 & 0.62 & 1.07 & 3.10 & 0.11 & 101 \\
JSB029-Cc1-01 & $\mathrm{CM}$ & 48.0 & 1.03 & 1.57 & 3.74 & 0.08 & 55.9 \\
JSB029-Cc1-02 & $\mathrm{CM}$ & 46.8 & 1.20 & 1.85 & 4.30 & 0.06 & 54.2 \\
JSB044-Cc1-01 & $\mathrm{CM}$ & 51.0 & 0.47 & 0.88 & 2.37 & 0.23 & 29.1 \\
JSB044-Cc1-02 & $\mathrm{CM}$ & 47.1 & 0.90 & 1.49 & 4.12 & 0.49 & 68.3 \\
JSB044-Cc1-03 & $\mathrm{CM}$ & 46.2 & 0.91 & 1.81 & 4.63 & 0.43 & 133 \\
JSB044-Cc1-07 & $\mathrm{CM}$ & 51.5 & 0.53 & 0.82 & 2.00 & 0.18 & 44.7 \\
JSB044-Cc1-08 & $\mathrm{CM}$ & 51.6 & 0.51 & 0.79 & 2.03 & 0.16 & 38.4 \\
JSB044-Cc2-01 & $\mathrm{CM}$ & 51.1 & 0.60 & 0.85 & 2.24 & 0.22 & 34.7 \\
JSB044-Cc2-02 & $\mathrm{CM}$ & 48.4 & 0.66 & 1.56 & 3.64 & 0.23 & 56.2 \\
JSB054-Cc3-01 & $\mathrm{CM}$ & 47.5 & 0.74 & 1.07 & 4.00 & 0.82 & 80.5 \\
JSB054-Cc3-02 & $\mathrm{CM}$ & 49.8 & 0.63 & 0.79 & 2.91 & 0.50 & 62.9 \\
JSB054-Cc3-03 & $\mathrm{CM}$ & 49.7 & 0.60 & 0.77 & 2.99 & 0.50 & 63.2 \\
JSB054-Cc3-04 & $\mathrm{CM}$ & 51.1 & 0.52 & 0.74 & 2.33 & 0.26 & 50.0 \\
JSB057-Cc3-01 & $\mathrm{CM}$ & 52.5 & 0.47 & 0.60 & 1.65 & 0.02 & 35.8 \\
JSB057-Cc3-04 & $\mathrm{CM}$ & 50.8 & 0.62 & 0.93 & 2.48 & 0.04 & 80.5 \\
JSB054-Cc1-03 & $\mathrm{CM}$ & 49.6 & 1.11 & 0.69 & 2.89 & 0.31 & 76.5 \\
JSB054-Cc1-04 & $\mathrm{CM}$ & 45.2 & 1.80 & 0.87 & 4.97 & 0.70 & 116 \\
\hline
\end{tabular}




\section{Table DR 4}

Sr content and Sr isotopic compositions of aragonite veinlets crosscutting one sample of the carbonatite intrusion.

\begin{tabular}{cccc}
\hline Sample & Sr (ppm) & ${ }^{87} \mathbf{S r}{ }^{\mathbf{8 6}} \mathbf{S r}$ & $\mathbf{2 \sigma}$ \\
\hline JSB15062-1 & 6022 & 0.70605 & 0.000015 \\
JSB15062-2 & 1610 & 0.70571 & 0.000039 \\
JSB15062-3 & 2700 & 0.70635 & 0.000034 \\
JSB15062-4 & 4909 & 0.70673 & 0.000016 \\
JSB15062-5 & 7848 & 0.70672 & 0.000013 \\
JSB15062-6 & 3654 & 0.70560 & 0.000019 \\
JSB15062-7 & 1545 & 0.70532 & 0.000047 \\
JSB15062-8 & 6442 & 0.70583 & 0.000027 \\
JSB15062-9 & 5005 & 0.70683 & 0.000017 \\
JSB15062-10 & 5005 & 0.70684 & 0.000021 \\
JSB15062-11 & 4941 & 0.70584 & 0.000030 \\
JSB15062-13 & 3246 & 0.70411 & 0.000039 \\
\hline
\end{tabular}




\section{References}

Armstrong-Altrin, J. S., Verma, S. P., Madhavaraju, J., Lee, Y. I., and Ramasamy, S., 2003, Geochemistry of Upper Miocene Kudankulam Limestones, Southern India: International Geology Review, v. 45, p. 16-26, doi: 10.2747/0020-6814.45.1.16.

Bühn, B., 2008, The role of the volatile phase for REE and Y fractionation in low-silica carbonate magmas: implications from natural carbonatites, Namibia: Mineralogy and Petrology, v. 92, p. 453-470, doi: 10.1007/s00710-007-0214-4.

Bell, K., Blenkinsop, J., Cole, T. J. S., and Menagh, D. P., 1982, Evidence from Sr isotopes for longlived heterogeneities in the upper mantle: Nature, v. 298, p. 251-253, doi: 10.1038/298251a0.

Bell, K., and Simonetti, A., 2010, Source of parental melts to carbonatites-critical isotopic constraints: Mineralogy and Petrology, v. 98, p. 77-89, doi: 10.1007/s00710-009-0059-0.

Bellanca, A., Masetti, D., and Neri, R., 1997, Rare earth elements in limestone/marlstone couplets from the Albian-Cenomanian Cismon section (Venetian region, northern Italy) : assessing REE sensitivity to environmental changes: Chemical Geology, v. 141, p. 141-152, doi: 10.1016/S0009-2541(97)00058-2.

Burke, K., Ashwal, L. D., and Webb, S. J., 2003, New way to map old sutures using deformed alkaline rocks and carbonatites: Geology, v. 31, p. 391-394.

Chen, L., Liu, Y.S., Hu, Z. C., Gao, S., Zong, K. Q., and Chen, H. H., 2011, Accurate determinations of fifty-four major and trace elements in carbonate by LA-ICP-MS using normalization strategy of bulk components as 100\%: Chemical Geology, v. 284, p. 283-295, doi: 10.1016/j.chemgeo.2011.03.007.

Gao, S., et al., 2004, Recycling lower continental crust in the North China craton: Nature, v. 432, p. 892-897, doi: 10.1038/nature03162.

Halama, R., McDonough, W. F., Rudnick, R. L., and Bell, K., 2008, Tracking the lithium isotopic evolution of the mantle using carbonatites: Earth and Planetary Science Letters, v. 265, p. 726742, doi: 10.1016/j.epsl.2007.11.007.

Hoernle, K., Tilton, G., Le Bas, M., Duggen, S., and Garbe-Schönberg, D., 2002, Geochemistry of oceanic carbonatites compared with continental carbonatites: mantle recycling of oceanic crustal carbonate: Contributions to Mineralogy and Petrology, v. 142, p. 520-542, doi: 10.1007/s004100100308.

Hou, Z. Q., Liu, Y., Tian, S. H., Yang, Z. M., and Xie, Y.L., 2015, Formation of carbonatite-related giant rare-earth-element deposits by the recycling of marine sediments: Sci Rep, v. 5, p. 10231, doi: 10.1038/srep10231.

Huang, Y. M., Hawkesworth, C. J., van Calsteren, P., and McDermott, F., 1995, Geochemical characteristics and origin of the Jacupiranga carbonatites, Brazil: Chemical Geology, v. 119, p. 79-99, doi: 10.1016/0009-2541(94)00093-N.

Jin, Z. J., Zhu, D. Y., Hu, W. X., Zhang, X. F., Zhang, J. T., and Song, Y.C., 2009, Mesogenetic dissolution of the middle Ordovician limestone in the Tahe oilfield of Tarim basin, NW China: Marine and Petroleum Geology, v. 26, p. 753-763, doi: 10.1016/j.marpetgeo.2008.08.005.

Jolis, E. M., Freda, C., Troll, V. R., Deegan, F. M., Blythe, L. S., McLeod, C. L., and Davidson, J. P., 2013, Experimental simulation of magma-carbonate interaction beneath Mt. Vesuvius, Italy: 
Contributions to Mineralogy and Petrology, v. 166, p. 1335-1353, doi: 10.1007/s00410-013-0931-0.

Keto, L. S., and Jacobsen, S. B., 1988, Nd isotopic variations of Phanerozoic paleoceans: Earth and Planetary Science Letters, v. 90, p. 395-410, doi: 10.1016/0012-821X(88)90138-0.

Klein, C., and Beukes, N. J., 1989, Geochemistry and sedimentology of a facies transition from limestone to iron-formation deposition in the early Proterozoic Transvaal Supergroup, South Africa.: Economic Geology, v. 84, p. 1733-1774.

Liu, Y. S., Gao, S., Lee, C.-T. A., Hu, S. H., Liu, X. M., and Yuan, H. L., 2005, Melt-peridotite interactions: Links between garnet pyroxenite and high-Mg\# signature of continental crust: Earth and Planetary Science Letters, v. 234, p. 39-57, doi: 10.1016/j.epsl.2005.02.034.

Liu, Y. S., He, D. T., Gao, C. G., Foley, S. F., Gao, S., Hu, Z. C., Zong, K. Q., and Chen, H. H., 2015, First direct evidence of sedimentary carbonate recycling in subduction-related xenoliths: Scientific Reports, v. 5, p. 11547, doi: 10.1038/srep11547.

Liu, Y. S., Zong, K. Q., Kelemen, P. B., and Gao, S., 2008a, Geochemistry and magmatic history of eclogites and ultramafic rocks from the Chinese continental scientific drill hole: Subduction and ultrahigh-pressure metamorphism of lower crustal cumulates: Chemical Geology, v. 247, p. 133-153, doi: 10.1016/j.chemgeo.2007.10.016.

Liu, Y. S., Hu, Z. C., Gao, S., Guenther, D., Xu, J., Gao, C. G., and Chen, H. H., 2008b, In situ analysis of major and trace elements of anhydrous minerals by LA-ICP-MS without applying an internal standard: Chemical Geology, v. 257, p. 34-43, doi: 10.1016/j.chemgeo.2008.08.004.

Mitchell, R. H., 2005, Carbonatites and carbonatites and carbonatites.: The Canadian Mineralogist, v. 43, p. 2049-2068, doi: 10.2113/gscanmin.43.6.2049.

Mourao, C., Mata, J., Doucelance, R., Madeira, J., da Silveira, A. B., Silva, L. C., and Moreira, M., 2010, Quaternary extrusive calciocarbonatite volcanism on Brava Island (Cape Verde): A nephelinitecarbonatite immiscibility product: Journal of African Earth Sciences, v. 56, p. 59-74, doi: 10.1016/j.jafrearsci.2009.06.003.

Rudnick, R. L., Gao, S., Ling, W. L., Liu, Y. S., and McDonough, W. F., 2004, Petrology and geochemistry of spinel peridotite xenoliths from Hannuoba and Qixia, North China craton: Lithos, v. 77, p. 609-637, doi: 10.1016/j.lithos.2004.03.033.

Song, Y., Frey, F. A., and Zhi, X., 1990, Isotopic characteristics of Hannuoba basalts, eastern China: Implications for their petrogenesis and the composition of subcontinental mantle: Chemical Geology, v. 88, p. 35-52, doi: 10.1016/0009-2541(90)90102-D.

Tanaka, K., Miura, N., Asahara, Y., and Kawabe, I., 2003, Rare earth element and strontium isotopic study of seamount-type limestones in Mesozoic accretionary complex of Southern Chichibu Terrane, central Japan: Implication for incorporation process of seawater REE into limestones: Geochemical Journal, v. 37, p. 163-180.

Tsikos, H., Moore, J. M., and Harris, C., 2001, Geochemistry of the Palæoproterozoic Mooidraai Formation: Fe-rich limestone as end member of iron formation deposition, Kalahari Manganese Field, Transvaal Supergroup, South Africa: Journal of African Earth Sciences, v. 32, p. 19-27, doi: 10.1016/S0899-5362(01)90016-8.

Veizer, J., 1985, Carbonates and Ancient Oceans: Isotopic and Chemical Record on Time Scales of 107109 Years, The Carbon Cycle and Atmospheric CO2: Natural Variations Archean to Present, American Geophysical Union, p. 595-601.

Veizer, J., et al., 1999, ${ }^{87} \mathrm{Sr} /{ }^{86} \mathrm{Sr}, \delta^{13} \mathrm{C}$ and $\delta^{18} \mathrm{O}$ evolution of Phanerozoic seawater: Chemical Geology, v. 
161, p. 59-88, doi: 10.1016/S0009-2541(99)00081-9.

Wells, P. R. A., 1977, Pyroxene thermometry in simple and complex systems: Contributions to Mineralogy and Petrology, v. 62, p. 129-139, doi: 10.1007/bf00372872.

Xu, R., Liu, Y. S., Tong, X. R., Hu, Z. C., Zong, K. Q., and Gao, S., 2013, In-situ trace elements and Li and $\mathrm{Sr}$ isotopes in peridotite xenoliths from Kuandian, North China Craton: Insights into Pacific slab subduction-related mantle modification: Chemical Geology, v. 354, p. 107-123, doi: 10.1016/j.chemgeo.2013.06.022.

$\mathrm{Xu}$, Y. G., 2002, Evidence for crustal components in the mantle and constraints on crustal recycling mechanisms: pyroxenite xenoliths from Hannuoba, North China: Chemical Geology, v. 182, p. 301-322, doi: 10.1016/S0009-2541(01)00300-X.

Yan, G. H., Mu, B. L., Zeng, Y. S., Cai, J. H., Ren, K. X., and Li, F. T., 2007, Igneous Carbonatites in North China Craton: The Temporal and Spatial Distribution, Sr and Nd Isotopic Charateristics and Their Geological Significance (in Chinese with English abstract): Geological Journal of China Universities, v. 13, p. 463-473. 